\title{
Bratovština kovača u Zadru i njezina matrikula iz 15. stoljeća
}

Matrikula Bratovštine kovača u Zadru pohranjena je u Znanstvenoj knjižnici u Zadru. $\mathrm{Na}$ temelju teksta matrikule razmotrit će se osnovne regule Bratovštine kovača u Zadru, prikazati njezino djelovanje i imena članova koji su spomenuti u matrikuli Bratovštine. Istražena dokumentacija usporedit će se s dosad objavljenom literaturom o Bratovštini kovača i nadopunit će se nedovršeni prikaz matrikule Vitaliana Brunellija iz 19. stoljeća. Cilj je rada ukazati na činjenicu da je Bratovština kovača u Zadru ustanovljena prije 1490. godine, kako je to pogrešno ustvrdio Brunelli, te otvoriti raspravu o njezinoj mogućoj poveznici s bratovštinom zadarskih zlatara.

Ključne riječi: Bratovština kovača, matrikula, Zadar, 15. stoljeće, Vitaliano Brunelli

\section{Uvod}

Matrikule dalmatinskih bratovština prvorazredno su povijesno vrelo za interdisciplinarno promatranje prošlosti južnoga dijela Hrvatske. Djelomičan prikaz literature koja se bavi ovim pitanjem objavio je Ivan Ostojić. ${ }^{1}$ Sustavnije izvješće o izvorima i literaturi o bratovštinama u Dalmaciji predstavila je Lovorka Čoralić. ${ }^{2}$ U opširnome prikazu zadarskih bratovština Vlado Cvitanović naveo je i obrtničku Bratovštinu kovača u Zadru. ${ }^{3}$ Cvitanović se pozvao na zapise zadarskoga povjesničara Carla Federica Bianchija te ustvrdio da je Bratovština postojala u Zadru prije 1413. godine, a da joj se početci mogu datirati već u 14. stoljeće. ${ }^{4} \mathrm{U}$ podnožnoj bilješci Cvitanović se pozvao na navod Vitaliana Brunellija da je ma-

\footnotetext{
Zdenko Dundović, Teološko-katehetski odjel Sveučilišta u Zadru, Trg kardinala Stepinca 1, 23000 Zadar, Republika Hrvatska, E-mail adresa: zdundovic@unizd.hr

1 Ivan Ostojić, "Stara bratovština presvetog Tijela Kristova u Splitu”, Bogoslovska smotra 46 (1977), br. 3: 319-320.

2 Lovorka Čoralić, "Izvori i literatura o bratovštinama u Dalmaciji od srednjeg vijeka do pada Mletačke Republike”, Croatica Christiana periodica 15 (1991), br. 27: 88-96.

3 Vlado Cvitanović, “Bratovštine grada Zadra”, u: Zadar Zbornik: geografija, ekonomija, saobraćaj, povijest, kultura, ur. Jakša Ravlić (Zagreb: Matica hrvatska, 1964), 461.

4 Usp. Carlo Federico Bianchi, Zara Cristiana I (Zara: Tipografia Woditzka, 1877), 509-510.
} 
trikula Bratovštine bila u biblioteci Paravia. ${ }^{5}$ Matrikulu je spomenuo Angelo de Benvenuti u svojemu radu, ${ }^{6}$ a citirana je i u studiji o Zadru pod mletačkom upravom. ${ }^{7} \mathrm{O}$ matrikuli Bratovštine kovača iz biblioteke Paravia u Zadru u nekoliko je navrata pisao Vitaliano Brunelli, ${ }^{8}$ pri čemu se kritički osvrnuo na zaključke koje je o bratovštini kovača iznio Carlo Federico Bianchi u svojemu djelu Zara Cristiana. Brunelli je pritom osnivanje Bratovštine kovača u Zadru datirao u 1490. godinu. Cilj je ove rasprave dokazati da je taj podatak netočan te da osnivanje Bratovštine kovača u Zadru treba tražiti koncem 14. ili početkom 15. stoljeća, odnosno da su zaključci Carla Federica Bianchija o tome pitanju točni. Nadalje, na temelju istraženoga arhivskoga gradiva i dosad objavljene literature u radu se postavlja hipoteza da se bratovština kovača - radi zaštite vlastitih interesa - u zasad nepoznatome razdoblju udružila s bratovštinom zadarskih zlatara. Konačno, u radu će se analizirati dokumenti iz matrikule bratovštine kovača u Zadru, koje Brunelli nije objavio u svojim tekstovima, a koji će pridonijeti boljemu razumijevanju prošlosti, djelovanja i uzroka konačne dekadencije Bratovštine kovača u Zadru.

\section{Opis matrikule bratovštine kovača u Zadru}

Matrikula bratovštine kovača iz fonda Znanstvene knjižnice u Zadru dobro je očuvana, uvezana u tvrde, izblijedjele kožne korice, međusobno povezane dvjema metalnim spojnicama. Dimenzije su joj $31 \mathrm{~cm} \times 21 \mathrm{~cm}$, a proteže se na 50 stranica teksta. Matrikula sadrži 33 kapitula, čiji se prijepis donosi u prilogu (Prilog 1.). Važno je napomenuti da su, osim teksta pravila bratovštine, u matrikuli zabilježene razne potvrde i ovjere regula od strane mletačkih vlastodržaca, a vremenski se protežu u razdoblju od 15. do 18. stoljeća, s naglaskom da ne prate uvijek logično pretpostavljeni kronološki red. ${ }^{9} \mathrm{Na}$ verso strani prvoga folija matrikule oslikana je gruba minijatura, razdijeljena u dva polja, uokvirena trakom s cvjetnim ukrasima različitih boja. U gornjemu polju naslikan je lav, simbol evanđelista sv. Marka, zaštitnika Mletačke Republike, sa šapama položenima na evanđelistar. U desnoj šapi lava oslikan je mač, a u pozadini toranj na brežuljku, na vrhu kojega se razvija crvena zastava, simbol Mletačke Republike. U donjemu polju oslikan je prikaz heraldičkoga znakovlja mletačkih obitelji Corner, Loredan, Zorzi i da Mosto. Upravo je na temelju te heraldičke predstavke Brunelli zaključio da je matrikula zapravo prijepis stare matrikule Bratovštine kovača u Zadru, koju on datira u

5 Cvitanović, "Bratovštine grada Zadra", bilj. 29, 461.

6 Angelo de Benvenuti, Storia di Zara dal 1409 al 1797 (Milano: Fratelli Bocca, 1944), bilj. 101, 226.

7 Tomislav Raukar et al., Zadar pod mletačkom upravom (Zadar: Narodni list, Filozofski fakultet, 1987), bilj. 187, 386.

8 Vitaliano Brunelli, "Confraternita de' fabbri-ferrai in s. Domenica", Il Dalmata (Zadar) 8, 10, 11, 12, $13,14,17$ (1877).

9 Na to je već upozorio Brunelli, Il Dalmata 8 (1877). 
1628. godinu. ${ }^{10}$ Brunellijev je zaključak logičan i opravdan, no njegova tadašnja pretpostavka o dataciji osnivanja bratovštine kovača u Zadru je pogrešna.

Matrikulu Bratovštine kovača u Zadru ratificirao je zadarski knez Marco Bembo 20. travnja 1491. godine, ${ }^{11}$ a potvrdio generalni providur Paolo Erizzo 2. rujna 1499., kao i Bernardin Loredan i Nicolo Dolphin (procuratores et advocatores in Culfum) na zamolbu gastalda Mateja i protomagistra Luke, o čemu su upoznati zadarski knez Francesco Venerio i kapetan Giacomo de Molino. ${ }^{12}$

Slika 1. Uvodne stranice matrikule Bratovštine kovača u Zadru

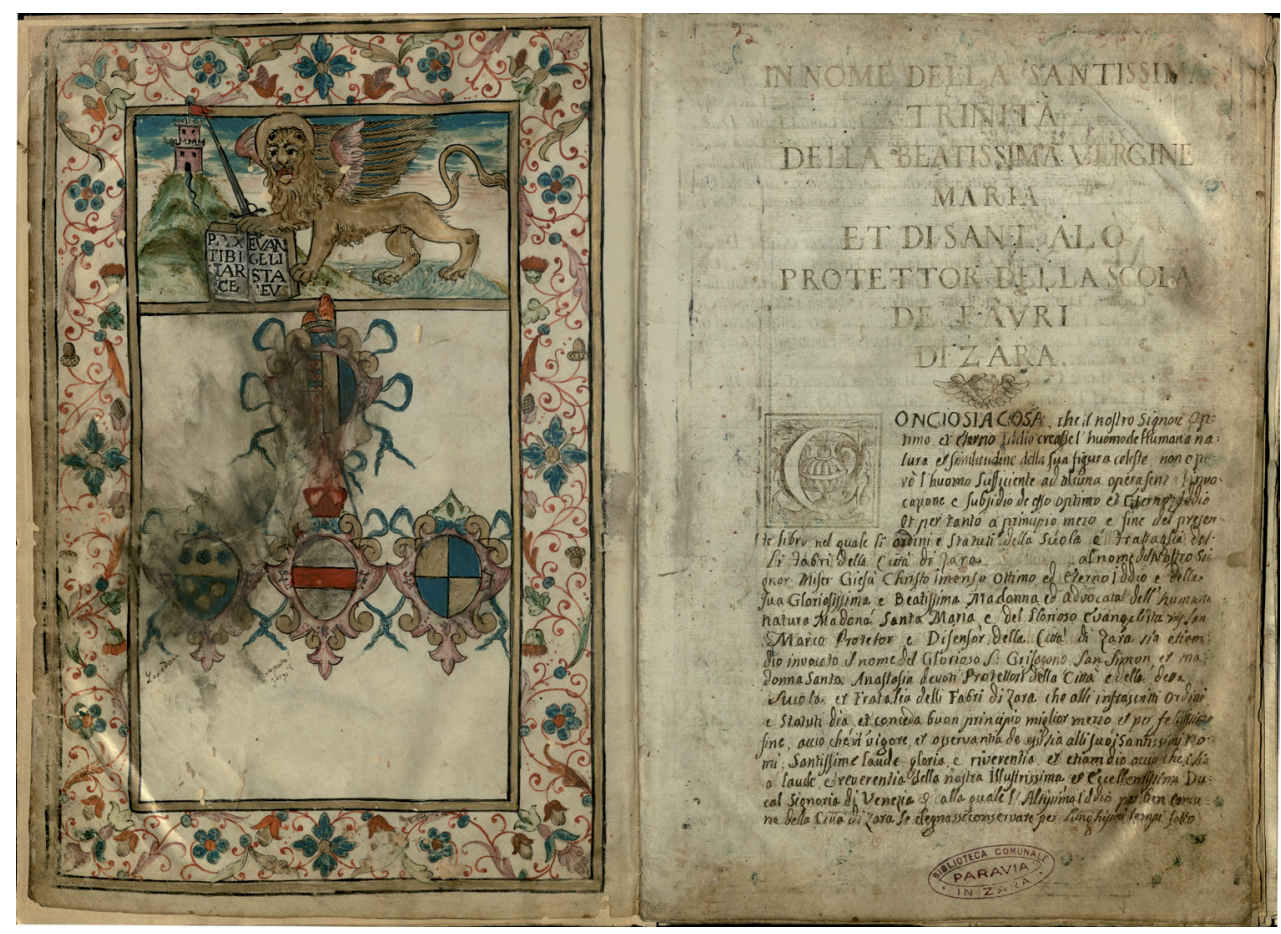

Izvor: ZKZD, sign. 10365, ms. 50.

\section{Kada je ustanovljena Bratovština kovača u Zadru?}

$\mathrm{Na}$ tragu gotovo sigurne pretpostavke da je matrikula Bratovštine kovača u Zadru zapravo prijepis iz 1628. godine ${ }^{13}$ originalnoga teksta matrikule od 1. rujna

${ }^{10}$ U godini 1628. mletački dužd bio je Giovanni Corner, generalni providur za Dalmaciju i Albaniju Alvise Zorzi, zadarski knez Bernardo Loredan, a zadarski kapetan Pietro da Mosto. Il Dalmata, 8 (1877).

${ }^{11}$ Hrvatska (dalje: HR) - Znanstvena knjižnica Zadar (dalje: ZKZD) - sign. 10365, ms. 50 (dalje: MS50)

- Mariegola de favri di Zara (dalje: Mariegola), fol. 6.

${ }^{12}$ HR-ZKZD-MS50-Mariegola, fol. 6-7.

${ }^{13}$ Nije neuobičajeno da su bratovštine tijekom svoga postojanja u više navrata prepisivale i nadopunjavale svoje matrikule novim kapitulima, osobito u 15. stoljeću kada su mletačke vlasti provele reviziju bratovštinskih statuta u Dalmaciji. Cvitanović, "Bratovštine grada Zadra", 458. 
1490. godine,$^{14}$ Brunelli je zaključio da se 1490 . godinu može smatrati vjerojatnom godinom ustanove Bratovštine kovača u Zadru. ${ }^{15}$ Pritom se kritički osvrnuo na različite podatke o osnivanju Bratovštine, koje je iznio zadarski kanonik i crkveni povjesničar Carlo Federico Bianchi. Bianchi je, naime, prvotno naveo da je Bratovština kovača u Zadru ustanovljena 1416. godine, ${ }^{16}$ a potom malo dalje da je ona postojala prije 1413. godine, što je Bianchi zaključio na temelju natpisa na relikvijaru sv. Klare, koji se čuvao u crkvi Bratovštine kovača. ${ }^{17}$ Brunelli je stoga problematizirao Bianchijevu nedosljednost u dataciji osnivanja Bratovštine kovača te mu prigovorio nenavođenje izvora kojima se pritom služio jer je analizom latinskoga natpisa na relikvijaru sv. Klare ustvrdio da je Bratovština u posjed relikvijara došla 1501 . godine. ${ }^{18}$ Nadalje, u potvrdu svoga stajališta da je Bratovština utemeljena 1490. godine Brunelli se kritički osvrnuo na Binachijeva razmatranja prostornoga okvira predjela grada (Babe, la Pusterla) u kojemu su djelovali zadarski kovači kao i titulare njihove crkve u kojoj su se oni okupljali (S. Giovanni o s. Domenica). ${ }^{19}$ Konačno, Brunelli se u zadnjemu nastavku svojega osvrta na matrikulu zadarskih kovača usredotočio na problematiku svetaca zaštitnika Bratovštine, napose sv. Eligija (poznatoga i kao sv. Alò). ${ }^{20}$ Svi novinski članci u kojima se Brunelli doticao Bratovštine imali su za cilj potvrditi njegovu pretpostavku o dataciji osnivanja Bratovštine kovača u Zadru 1490. godine. Iako je Brunelli u posljednjemu novinskom članku o Bratovštini kovača u Il Dalmati najavio nastavak rasprave, do toga (zbog nepoznatoga razloga) nije došlo.

U odnosu na svoju prvotnu pretpostavku o ustanovi Bratovštine kovača u Zadru, Brunelli je kasnije iznio dokaz o njezinomu postojanju prije 1490. godine. U raspravi o crkvi Sv. Ivana de Pusterla ili pučki sv. Nediljice (S. Domenica) Brunelli je spomenuo dvoranu, naslonjenu na crkvu, veličine $5.70 \mathrm{~m} \times 6.50$ metara, u kojoj su se okupljali bratimi. ${ }^{21}$ Pritom je u bilješci zapisao: È gia nominata nei protocolli del notaio de Benedictis: fratalea s. Dominice fabrorum de Jadra (testam. 1441, 17 dec.).22 Dakle, oporuka koju navodi Brunelli potvrđuje postojanje Bratovštine kovača i crkvu Sv. Nediljice u njzienomu posjedu barem od 1441. godine. Moguće je dijelom zaključiti da Brunelli nije nastavio raspravu u Il Dalmati vjerojatno jer je došao do novih saznanja tijekom istraživanja zadarskih arhiva i isprava.

\footnotetext{
${ }_{14}$ Millesimo Quadrigentesimo Nonagesimo Indictione Octava Die vero prima mensis Septembris Iadrae. HR-ZKZD-MS50-Mariegola, fol. 2.

15 Il Dalmata 11 (1877).

${ }_{16}$ Bianchi, Zara Cristiana I, 413.

17 Isto, 509.

${ }^{18}$ Il Dalmata 10, 11 (1877).

19 Il Dalmata 13 (1877).

${ }^{20}$ Il Dalmata 17 (1877).

${ }^{21}$ Vitaliano Brunelli, Storia della Città di Zara (Trieste: Edizioni Lint, 1974), 256.

${ }^{22}$ Isto, bilj. 55, 264.
} 
O opstojanju Bratovštine kovača prije 1490. godine svjedoči relikvija križa (una croce d'argento dorata) s natpisom Hoc opus fieri fecit Fraternitas Fabrorum, što su je zadarski kovači 1446. godine naručili kod zadarskih zlatara. ${ }^{23}$ Brunelli se osvrnuo na dio natpisa te relikvije u kojemu stoji: quod perfecit Dominus Mathaeus de Matapharis te je ustvrdio da Mateo Matafar nije mogao izraditi relikviju jer je pripadao zadarskome plemstvu, nego je relikvija vjerojatno izrađena ili je njezina izrada dijelom potpomognuta plemićevim novcem. ${ }^{24}$ Međutim, Klaić i Petricioli navode da su sinovi nekih zadarskih plemenitaša bili zanatlijski šegrti kod zadarskih zlatara ${ }^{25}$ pa Brunellijev zaključak treba uzeti oprezno.

Stoga se čini vjerojatnijim Bianchijev zaključak o ustanovi Bratovštine kovača početkom 15. stoljeća, moguće i koncem 14. stoljeća, sa sjedištem u crkvi Sv. Ivana Krstitelja (Sv. Nediljice) u Zadru. ${ }^{26}$ Konačno, s obzirom na Brunellijevu raspravu o predjelu Babe u Zadru, nužno je napomenuti da se u zadarskome katastiku iz 15. stoljeća (1421. godine), koji je objavio Stjepan Antoljak, spominje nekoliko kovača nominalno hrvatskoga podrijetla: magister Ellias faber, Petrus Martinovich faber, Simon Milgostich faber, Ratchi Limnaz faber, Marcus Stipanich faber, Milchus Gignasto faber, Vladislavus faber de Jadra, Bellica relicta Martini fabri, Juraij Magonaz faber de Jadra, Petrus Lucich faber, Millenoij Velcich faber, Paulus Chercota faber, a svi su oni smješteni u predjelu Babe u Zadru (positi Jadre in confinio Bebarum) ${ }^{27}$ Neosporno je, dakle, Brunellijev zaključak o osnivanju Bratovštine zadarskih kovača 1490. godine pogrešan. Vjerojatnije je da su te godine potvrđena pravila stare regule Bratovštine kovača na tragu spomenute revizije bratovštinskih pravila u Dalmaciji od strane mletačke vlasti. Mletačka magistratura, koja je vodila brigu o udruženjima obrtnika i obrtima u Veneciji te odobravala bratovštinske matrikule, naziva se Giustizia vecchia (1278.-1797.). Udruženja obrtnika bila su od posebnoga značenja za Mletačku Republiku, o čemu svjedoče reljefni prikazi rada raznih zanatlija na ulazu u Baziliku sv. Marka (arco dei mestieri), jednoga od simbola mletačke moći. ${ }^{28}$ Tu se vidi i prikaz kovača. ${ }^{29}$

U fokusu našega razmatranja obrtničke su bratovštine. Nada Klaić i Ivo Petricioli tvrde da obrtničkih bratovština u Zadru u 12. i 13. stoljeću nema iako Bianchi navodi postojanje zadarske Bratovštine zlatara od 1176. godine, ${ }^{30}$ što spomenuti

\footnotetext{
${ }^{23}$ Bianchi, Zara Cristiana I, 414.

24 Il Dalmata 10 (1877).

${ }^{25}$ Usp. Nada Klaić, Ivo Petricioli, Zadar u srednjem vijeku, (Zadar: Filozofski fakultet, 1976), 479.

${ }^{26}$ O crkvi više kod: Pavuša Vežić, "Bazilika Sv. Ivana Krstitelja (Sv. Nediljica) u Zadru. Prilog poznavanju ranoromaničke arhitekture u Dalmaciji”, Radovi Instituta za povijest umjetnosti 23 (1999): 7-16.

${ }^{27}$ Stjepan Antoljak, "Zadarski katastik 15. stoljeća”, Starine JAZU u Zagrebu 42 (1949): 379-382.

${ }^{28}$ Mario Saverio di Martiis, "Lavoro e salute in Europa prima della rivoluzione industriale", Rivista degli infortuni e delle malattie professionali 1 (2010): 133-134.

${ }^{29}$ Vidi sliku kod: Joško Belamarić, "Šutnja protomajstora bazilike San Marco u Veneciji - razriješena", Radovi Instituta za povijest umjetnosti 12-13 (1988-1989): 99.

${ }^{30}$ Bianchi, Zara Cristiana I, 508.
} 
dvojac osporava ${ }^{31}$ Iako autori drže da su obrtničke bratovštine u Zadru organizirale tek mletačke vlasti nakon 1409. godine, spominju postojanje jedne obrtničke organizacije u Zadru, a to je bila fratalea artis calegariorum, Bratovština postolara, koju oni povezuju s kožarskim obrtom u Zadru, ${ }^{32}$ što je neobično važno za našu raspravu. U Zadru je u drugoj polovici 14. stoljeća kovačka struka po opsegu proizvodnje imala prvenstvo; kovači su mahom bili stranci, a u kovačnice se ulagao strani kapital. Glavni osnivač Velike kovačnice u Zadru bio je Venturin pok. Pazina iz Cesene, a kovačnica je bila smještena u kući koja je pripadala samostanu Sv. Krševana. Prema istraživanju Klaićeve i Petriciolija Venturin je imao najmanje sedmoricu majstora i radnika, a spominju se čavlari, kotlari i učenici kovačkoga zanata. ${ }^{33}$ Venturin je napustio kovačnicu 1377. godine, vjerojatno zbog zaduženosti, jer su jedan njezin dio prodala tri zadarska patricija, ujedno jamca, za sedamsto libara kako bi se namirio Venturinov dug Ivanu de Nassisu, jednome od jamaca, a kovačnicu je preuzeo Simon de Gnochis iz Genove. Uz Venturinovu radionicu poznata je još barem jedna, nešto skromnija, koju je 1382. godine zakupio kovač Milacije, Radogostov sin, od kovača Radice za 22 libre i 15 soldi, a 1384. godine prodao ju zadarskom notaru Petru pokojnoga Bartolomeja iz Sarzane. ${ }^{34}$ Bila je to potleušica s ljevaonicom kovina koja se nalazila u Zadru u župi Pusterla, a prodana je notaru za 65 lira. ${ }^{35}$ Petar iz Sarzane dao je 1384. godine kovačima Matolu pokojnoga Dominika i Milaciju pokojnoga Radogosta isti prostor u najam. ${ }^{36}$ Dakle, uz strane kovače razvidno je da u Zadru djeluju i domaći. Klaić i Petricioli naglasili su da jedna manja kovačka radionica prelazi u ruke kapitalista $i$ novi vlasnik pretvara obrtnike u svoje radnike ${ }^{37}$ pa zaključuju da je utjecaj patricijskoga kapitala bitno utjecao na proizvodnju u kovačkoj struci. ${ }^{38}$ Uzme li se u obzir da je (već spomenuta) Bratovština postolara osnovana dijelom radi zaštite posla, a dijelom radi zajedničkoga vlasništva nad kožarom, koja je u smislu proizvodnoga procesa sestrinski obrt postolarskoga zanata, nije li opravdana pretpostavka da su upravo zbog nepovoljnoga položaja prema patricijima (odnosno njihovu kapitalu) koncem 14. stoljeća i zadarski kovači nastojali osnovati bratovštinu ili se barem neformalno udružiti s nekom bratovštinom slične naravi, tim više, kako je razvidno iz zadarskoga katastika iz 15. stoljeća, što je u Zadru zabilježen i razmjerno visoki udio kovača domaćega podrijetla? ${ }^{39}$

\footnotetext{
31 Klaić, Petricioli, Zadar u srednjem vijeku, 480-481.

32 Isto, 483.

33 Isto, 473.

34 Isto, 474.

${ }^{35}$ Branka Grbavac, "Svakodnevni život notara u jednoj kasnosrednjovjekovnoj dalmatinskoj komuni primjer Zadra”, Javni bilježnik 14 (2010), br. 33: 30.

36 Isto.

37 Klaić, Petricioli, Zadar u srednjem vijeku, 474-475.

38 Isto, 475.

39 Iako su postolari i kožari u Zadru dijelili zajedničke interese koncem 14. stoljeća, zasebna Bratovština kožara organizirana je 1410. godine. Cvitanović, "Bratovštine grada Zadra”, 461.
} 
Klaić i Petricioli navode da su zlatari bili u znatno boljemu položaju od kovača, što se tiče nabave sirovine, odakle i njihova relativna sloboda i neovisnost o kapitalu naručitelja, a i jedni i drugi bili su plaćeni po učinku. ${ }^{40} \mathrm{Na}$ tragu prakse koja je zabilježena na Apeninskome poluotoku moguće je izvesti zaključak o nekoj vrsti povezivanja zadarskih kovača i zlatara koncem 14 . stoljeća ili početkom 15 . stoljeća radi zaštite vlastitih interes. ${ }^{41}$ Toj pretpostavci podlogu nalazimo u matrikuli Bratovštine zlatara u Zadru gdje je izrijekom navedeno da je Bratovština zlatara nekada imala dodirne točke s Bratovštinom kovača. ${ }^{42}$

No, koja bi odrednica bila zajednička kovačima i zlatarima u to doba? Spomenuto je da je Vitaliano Brunelli problematizirao svetce zaštitnike Bratovštine kovača u Zadru. Jedan od svetaca zaštitnika Bratovštine kovača jest sv. Eligije (sv. Alò). Kult sv. Eligija poveznica je između zlatara i kovača s obzirom na to da ga od srednjega vijeka i jedni i drugi štuju kao zaštinika ${ }^{43}$ Postoje brojni primjeri iz 14. i 15. stoljeća, napose na Apeninskome poluotoku, o udruživanju kovača i zlatara upravo po toj poveznici, a ta su se udruženja nazivala skupnim imenom Paraticum Ferrariorum. ${ }^{44}$ Primjerice, u Camerinu su se od 1424 . godine udružili u jednu bratovštinu pod zaštitom sv. Eligija zlatari, kovači i ostali metalurški obrtnici, a 1601. godine reformirali su stare statute, koje je 1605. godine potvrdio kardinal Pietro Aldobrandini. ${ }^{45}$ Uz to, iako se sv. Eligije (sv. Alò) držao svetcem zaštitnikom mnogih bratovština vezanih uz metalurški obrt u Europi, znale su se one nazivati po imenu crkve ili samostana u kojima se bratovština okupljala, a u njima se nalazio svečev oltar. ${ }^{46}$ Stoga nije neobična višestruka i raznolika uporaba naziva za Bratovštinu zadarskih kovača tijekom stoljeća. Razvidno je to iz dokumenta

\footnotetext{
${ }^{40}$ Klaić, Petricioli, Zadar u srednjem vijeku, 479.

${ }^{41}$ Iako se ne uklapa u kontekst rada, napominje se kao kuriozitet natpis iz rimskoga doba, pronađen $\mathrm{u}$ Apulumu (rimska provincija Dacia) na kojemu stoji: scola fabrorum aurariorum. Jordi Perez González, "Aurifices en la Roma Julio Claudia. La fiebre del oro romana", Studia antiqua et archaeologica 23 (2017), br. 1: 43. Njemački povjesničar Ferdinand Gregorovius (1821. - 1891.) zapisao je u svojemu djelu Storia della Città di Roma nel Medioevo da su rimski zlatari sve do 1509. godine bili u udruženju s rimskim kovačima. Università e nobil Colleggio degli orefici, gioelleri, argentieri dell’alma Città di Roma. La storia, pristup ostvaren 6. prosinca 2018., http://www.universitadegliorefici.it/la_storia.php

42 (...) che quella (bratovština, nap. a.) de Orefici (...) hà qualche relazioni con l'altra de’ Fabri. Hrvatska (dalje: HR) - Arhiv Zadarske nadbiskupije (dalje: AZDN) - fond 52, Varie/Razno, Matrikula bratovštine zlatara, fol. 68.

${ }^{43} \mathrm{O}$ tome više kod: Rosanna Bianco, "Culto e iconografia di sant'Eligio in Puglia tra Medioevo ed età moderna”, Studi Bitontini 95-98 (2013-2014): 7-26.

${ }^{44}$ Paraticum je pojam koji se u srednjemu vijeku rabio za cehove trgovaca i obrtnika. Vidi: Carla Almansi Sabbioneta, ur., L'Arte degli Orefici. Storie di mercati, mercanti ed artigiani in Cremona dal Trecento all'Ottocento (Cremona: Camera di commercio, 2006), 6; Filippo Galletti, "Le società delle arti a Bologna e i loro statuti: un bilancio storiografico", I quaderni del m.x.s 15 (2017): 77.

${ }^{45}$ Pietro Aldobrandini, Statuti, riformationi, et ordini dell'Università, et huomini dell'Arte de fabri, \& orefici della ilustre Città, e Stato di Camerino, confirmati, et approvati da' sig. padroni di Roma, (Camerino: Gioioso Francesco, 1613); Bianco, "Culto e iconografia di sant'Eligio", 8-9.

${ }^{46} \mathrm{Zbog}$ toga se često tijekom stoljeća Bratovština kovača u ispravama naziva imenom S. Domenica odnosno S. Zanne de’ Fabri. Il Dalmata 17 (1877). Usp. Klaić, Petricioli, Zadar u srednjem vijeku, 481.
} 
od 3. studenoga 1719. godine kada se Bratovština utekla zadarskome nadbiskupu Vicku Zmajeviću (1713.-1745.) da joj dopusti proširenje jedne prostorije, koja je služila kao sakristija. U ispravi zamolbe bratovština se naziva Confraterna della $B$. V. del Rosario ${ }^{47}$ ò sia S. Alò in S. Domenica di Fabri. U odgovoru nadbiskupa Zmajevića, kojim se dopušta proširenje, on bratovštinu oslovljava Confraternitatis Fabrorum sub titulo Sancti Alò in Ecclesia S.ti Joannis in Posterla vulgo S. Dominica. ${ }^{48}$

Nadalje, bratovštine su znale imati po nekoliko svetaca zaštitnika. Primjerice, Bratovština kovača u Veneciji štovala je uz sv. Eligija još i sv. Liberala, sv. Karla Boromejskoga i sv. Ivana Krstitelja. ${ }^{49} \mathrm{U}$ vrijeme gastalda Zuannea Spadera 1651. godine Bratovština kovača u Zadru molila je zadarskoga nadbiskupa Bernarda Florija da im odobri prikupljanje milostinje po gradu o uočnici sv. Alòa i sv. Klare $-\mathrm{s}$ obzirom na to da se relikvija ruke sv. Klare čuvala u njihovoj crkvi. ${ }^{50} \mathrm{Nad}-$ biskup je to dopustio uz uvjet (cum onere) da se slavi sv. misa na Dan sv. Klare u crkvi Sv. Ivana Kovačkoga, ${ }^{51}$ što potvrđuje da je Bratovština kovača u Zadru štovala sv. Klaru. O tome postoji neupitno svjedočanstvo i u ispravama Arhiva Zadarske nadbiskupije iz 18. stoljeća. Naime, tijekom 18. stoljeća sve su zadarske bratovštine i pobožne ustanove (luoghi pii) prikupljale milostinju po gradu po točno određenome rasporedu. Ako bi bratovštine potraživale milostinju za proslavu svoga zaštitnika ili bilo koju drugu potrebu, to su činile u dane koje je odredio zadarski nadbiskup, a za sve je bratovštine vrijedila praksa da slobodno prikupljalu milostinju o uočnici Božića (Vigilia). U popisu zadarskih bratovština za 18. stoljeće tako stoji zapisano da je Bratovština kovača prikupljala milostinju o uočnici sv. Klare, čija se relikvija nalazila u njihovoj crkvi. ${ }^{52}$ Kada su francuske vlasti početkom 19. stoljeća, u vrijeme posljednjega gastalda Šimuna Kaštelanića, dokinule Bratovštinu kovača u Zadru, gubi se svaki trag toj relikviji iako je bila na popisu inventara u arhivu Namjesništva. ${ }^{53}$

U obrani svojih prava Bratovština kovača navodi da je jedna od najstarijh obrtničkih bratovština u Zadru (ha dalla più remota antichità la sua origine). ${ }^{54} \mathrm{O}$ tome dijelom svjedoči i isprava iz 1546. godine, za vrijeme majstora kovača Ljubimira

\footnotetext{
${ }_{47}$ Taj naziv Bratovštine proizlazi iz slavlja sv. Nediljice (S. Domenica), koje se obilježavao u nedjelju Gospe od Ružarija. Bianchi, Zara Cristiana I, 414.

${ }^{48}$ Zamolbu potpisuju gastald Antonio de Dominis te Gregorio Haruatini i Domenico Giancouich, prokuratori. HR-ZKZD-MS50-Mariegola, fol. 25.

${ }^{49}$ Alessandro Ervas, Gerolamo Fazzini, "Il ferro a Venezia", Archeo Venezia 15 (2005), br. 1-4: 1.

${ }^{50}$ Bianchi, Zara Cristiana I, 509.

${ }^{51}$ HR-ZKZD-MS50-Mariegola, fol. 20.

${ }^{52}$ Hrvatska (dalje: HR) - Arhiv Zadarske nadbiskupije (dalje:AZDN) - fond 16 - Zadarska nadbiskupija/metropolija, Liber Extraordinariorum II (1746-1767), fol. 32v-33r.

${ }^{53}$ Usp. Il Dalmata 10 (1877).

${ }^{54}$ Tra le più antiche Schuole dell'Arti fu la Nostra de Fabbri, come raccoglie dalla sua antica Institutione, e come tale era dell più privileggiate, e che poteva mantenere con lustro, e decoro il suo antichissimo Sacro Tempio. HR-ZKZD-MS50-Mariegola, fol. 28.
} 
(Lubimir). ${ }^{55}$ Isprava govori o sporu između zadarskih kovača i zlatara o redoslijedu sudjelovanja u gradskim procesijama, a s obzirom na dataciju od 31. srpnja zasigurno je riječ o procesiji u spomen na pripojenje Zadra Mletačkoj Republici 1409. godine. ${ }^{56}$ Sve su obrtničke bratovštine bile dužne sudjelovati u toj procesiji. O tome zorno svjedoče nove uredbe (Reformationes) Zadarskoga statuta, koje je donijela mletačka vlast. ${ }^{57}$ Ako se neki bratim ne bi odazvao procesiji, bio bi novčano kažnjen, a u slučaju Bratovštine kovača u Zadru, kazna je iznosila osam lira ${ }^{58}$ Tekst isprave zorno pokazuje da je redoslijed sudjelovanja neke bratovštine tijekom svečanih gradskih procesija određivao njezinu važnost, dignitet, a slijedom toga i starinu. ${ }^{59}$ Posrednik u sporu između Bratovštine kovača i zlatara bio je Ivan iz Coma, postolar i zadarski stanovnik, a odluku arbitraže potvrdio je zadarski knez Giacomo Antonio Moro u korist zadarskih zlatara: (...) quod Scola siue Fratalea Fabrorum ferrariorum in Processionibus faciendis debeat praecedere Scola et Fratalea Aurificium. ${ }^{60}$ Važno je pritom napomenuti da su obrtničke bratovštine bile izuzete iz nadležnosti komunalnoga suda u manjim prijestupima, koji su bili pridržani gastaldu. ${ }^{61}$ Činjenica da se Bratovština kovača sporila s jednom od najstarijih, ali i najuglednijih, bratovština u Zadru, zasigurno potvrđuje ugled i važnost Bratovštine kovača u gradu, što bi išlo u prilog njezinome ranom osnivanju.

\footnotetext{
${ }_{55}$ U Jelićevu popisu zadarskoga stanovništva u drugoj polovici 16. i početkom 17. stoljeća na nekoliko se mjesta spominje prezime Gliubimir, redovito povezano s kovačkim zanatom (Gliubimir Zuanne qu. Zuane fauro 1597.; Gliubimir Barica [Zuane fauro] 1580.; Gliubimir Perina [Martin Fauro] 1587.; Gliubimir Margareta [qu. Zuane fauro] 1594.; Gliubimir Michel 1604 [fauro?], što daje za pravo zaključiti da se i u ispravi matrikule radi o prezimenu, a ne o imenu. Uz to, s obzirom na činjenicu da se u svojstvu gastalda Bratovštine u ispravi navodi Šimun Stahar, moguće je pretpostaviti da je Liubimir bio glavni majstor (protomagister) kovačkoga zanata. Roman Jelić, "Stanovništvo Zadra u drugoj polovici XVI. i početkom XVII. stoljeća gledano kroz matice vjenčanih”, Starine 49 (1959): 400, 480.

${ }^{56}$ HR-ZKZD-MS50-Mariegola, fol. 39-42.

57 (...) neka se sveudilj svake godine posljednjega dana mjeseca srpnja, to jest dana kada je prije spomenuto naše presvijetlo vrhovništvo u Mlecima ponovno zadobilo svoj grad Zadar, održava svečani ophod po prije rečenome gradu, sa svećenstvom i narodom. U tom ophodu neka stupaju pripadnici svakoga umijeća zasebno korak po korak sa svojim svijećama i drugim svečanim ukrasima, po hvalevrijednom običaju koji je do sada poštivan. Završetkom ophoda na dan 31. srpnja nijedan obrtnik u gradu i njegovoj varoši nije smio raditi, pod prijetnjom kazne od dvije male libre. Josip Kolanović, Mate Križman (ur. i prev.), Zadarski statut: sa svim reformacijama odnosno novim uredbama donesenima do godine 1563. (Zadar; Zagreb: Matica hrvatska, Ogranak; Hrvatski državni arhiv, 1997), R. 1, 521, R. 3, 523.

${ }^{58}$ HR-ZKZD-MS50-Mariegola, kap. XXV, fol. 4.

59 Nos Magister Joannes de Como Sutor et habitator Jadrae Judex Arbiter Arbitrator, et amicabilis Compositor electus et assumptus per Fabros ferrarios et Aurifices hujus Ciuitatis de et super lite differentia et Controuersia inter ipsos Vertent(iae) causa et occasione praecedendi in Processionibus, ac digniorem locum in eis habendi, ut in compromisso hodie in nos facto. Isto, fol. 39.

${ }^{60} \mathrm{Uz}$ to, Bratovština kovača bila je dužna isplatiti Bratovštini zlatara šest dukata, a obje strane bile su dužne podijeliti troškove spora u visini od šezdeset dukata. Gastald Bratovštine kovača bio je tada Šimun Stahar (Simeone Stahar), a gastald Bratovštine zlatara Ivan Callo (Joanne Callo). Isto, fol. 40-41. ${ }^{61}$ Isto, kap. XXII., fol. 4. Usp. Irena Benyovsky, "Bratovštine u srednjovjekovnim dalmatinskim gradovima”, Croatica Christiana periodica 22 (1998), br. 41: 151-152.
} 


\section{Što se iščitava iz zapisa matrikule o Bratovštini kovača u Zadru?}

U novinama Il Dalmata Brunelli nije do kraja analizirao dokumente iz matrikule Bratovštine kovača u Zadru. Uz 33 kapitula matrikula sadrži i zapise o nadopuni bratovštinskih pravila te dokumente svjetovnih i crkvenih vlasti o pravima i dužnostima Bratovštine. Navest će se ponajprije nadopune kapitula Bratovštine kovača kronološkim redom, a zatim se usredotočiti na funkcionalni aspekt Bratovštine radi očuvanja zanatskoga interesa.

Poput ostalih bratovština u Dalmaciji i Bratovština kovača u Zadru regulira prava i dužnosti svojih članova matrikulom i njezinim kapitulima. Na čelu Bratovštine stajao je gastald, kojemu su u radu pomagala dvojica prokuratora. Služba gastalda trajala je godinu dana, a birao se na godišnjoj skupštini Bratovštine balotažom. Gastald i prokuratori činili su upravno tijelo Bratovštine i zadaća im je bila voditi brigu o pravnim poslovima, vjerskome i moralnome stanju bratima, ekonomskome poslovanju i slično. Ujedno, oni su komunicirali s državnim i crkvenim vlastima u interesu Bratovštine. Bratovština je imala svoga kapelana, a u matrikuli je 1490. godine u tome svojstvu spomenut don Mate Usanić (Pre Mattio Usanich). Imala je i glavnoga majstora (Protomagister). ${ }^{62}$ Bratovština je bila živi organizam koji se prilagođavao novonastalim okolnostima i mijenjao ili nadopunjavao statute ovisno o okolnostima koje su mogle utjecati na njezin razvoj. Bratovština je po svojoj naravi bila interesna skupina korporativnoga karaktera.

Prva nadopuna kapitula uslijedila je 21. studenoga 1575 . godine. ${ }^{63}$ Bratovština je zamolila zadarskoga kneza da potvrdi kapitul kojim se određivalo da svaki bratim o Božiću treba dati Bratovštini torcu (velika svijeća) težine jedne libre za sprovodne obrede bratima te četiri mala solda za milostinju sprovodne mise, a kada ponestane svijeća, bili su obvezni nabaviti drugu iste težine. Onaj tko ne bi ispunio tu obvezu, za kaznu je trebao pribaviti dvostruko svijeća i milostinje za misu. Nadopunu kapitula odobrio je zadarski knez Alvise Pasqualigo. ${ }^{64}$ Dva nova

${ }^{62}$ HR-ZKZD-MS50-Mariegola, fol. 2.

${ }^{63}$ Navode se sljedeći članovi: gastald Šimun Brakusović (Bracusouich), prokuratori Zorzi Morador i Kristofor Montebro te bratimi Mattio Staor, Francesco Maron spader, Mattio de Scardona q. Bartholomeo, Martin suo fratello fauro, Zuanne Bradich, Antonio Rusin, Zuanne Brincich, Simon Sisich, Andrea Spader, Lazar kovač (favro), Piero Burato Spader, Domenego de Scutari kovač, Lorenzo Magan q. Andrea, Vido Giurisich, Marco Barcot, Luca fauro stagner et fonditor, Baldissera suo fratello stagner et fonditor, Andrea Unghero Schiopeter, Simon Liparelli schiopeter, Mattio Tedesco schiopeter, Antonio Capeletto, Carlo q. Antonio de Valsasina, Piero de Buoni Martini, Francesco Pagialonga. Isto, fol. 7.

${ }^{64}$ Che cadauno de i fratelli della Scola de Santa Domenica di Zara, che lauorano, et de caetero lauoraranno di ferro debbiano per le feste della Natiuità del nostro Sig.r Giesu Christo proxime uenture effetualmente dare alla sudetta loro Scuola una Torza per uno di cera lauorata de lire una di peso per ogni torza per le exequie de loro fratelli, et soldi quattro de piccioli per cadauno in elemosina delle messe, che saranno celebrate, et che si celebraranno al morto ad ogni exequie, ò uero mortorio, et quando ueranno à mancare esse torze, che di tempo in tempo siano tenuti, et obligati darne delle altre dello stesso peso, et cera lauorada, et chi mancarà, che resti condennato, si come per lo tenor del presente capitulo, e condennato à pagare per il doppio alla detta Scuola si delle torze, come de i quattro soldi senza ueruna resmissione, et che non se li possa far gratia de sorte alcuna.

Aluise Pasqualigo Conte affermo ut supra. Isto, fol. 8. 
kapitula Bratovština je donijela 27. prosinca 1614. godine. Tada je određeno da svaki bratim treba dati prve nedjelje u mjesecu četiri solda za kupnju sprovodnih svijeća i onih za procesije. Drugi kapitul obvezivao je bratime na redovitu nazočnost svetoj misi prve nedjelje u mjesecu, s kaznom od deset soldi za prekršitelje u korist crkve Sv. Nediljice. Kapituli su prihvaćeni sa šesnaest glasova za, a četiri protiv. Konačno ih je odobrio zadarski knez Lorenzo Suriano. ${ }^{65}$

Dana 19. lipnja 1642. godine bratimi su se okupili u sala solita della loro congregatione $^{66}$ uz dopuštenje zadarskoga kneza. Izglasao se novi kapitul o svetkovanju zaštitnika sv. Alòa, čiji se spomen slavio na 25. lipnja. Tko se ne bi odazvao svetkovini, bio je kažnjen s tri lire, a kovačima koji bi na taj dan radili odmjerile su se 22 lire kazne. Od toga se polovica iznosa uplaćivala u fiskalnu komoru, a druga polovica za potrebe bratovštinske crkve. Za gastalda i prokuratore ta je kazna iznosila deset lira. Dodatak matrikuli (novi kapitul o slavlju zaštitnika kovača) 1642. godine odobrio je zadarski knez Giovanni Battista Benzon 3. srpnja 1642. ${ }^{67}$ U popisu članova navodi se ime Šimuna Arvatinija, koji se 1664. godine spominje kao glavni kovački majstor (proto di favri in questa Città) u kupoprodajnome ugovoru kojim on prodaje samostanu Sv. Frane u Zadru svoju zidanu kućicu, smještenu u četvrti sS. Marije za stotinu dukata. ${ }^{68}$ Očito je obitelj Arvatini njegovala kovački obrt s obzirom da se nekoliko članova te zadarske građanske obitelji spominje i u matrikuli. Ujedno, gornje nadopune kapitula navode na zaključak da bratimi nisu u dovoljnoj mjeri ispunjavali religijske odredbe vlastite matrikule. Tijekom 18. stoljeća članstvo Bratovštine kovača znatno se smanjilo, a time je oslabila i njezina ekonomska moć. Razvidno je da se pravila matrikule nisu obdržavala pa se Bratovština utekla zadarskome knezu za njihovim ponovnim oživljavanjem kroz tri nova kapitula. Gastald Girolamo Antonelli i prokuratori Santo Pio i Giovanni Battista Golin tražili su od zadarskoga kneza Bartolomeja Trevisana 1733. godine u ime petnaest članova bratovštine, a pravno ih je zastupao odvjetnik Antonio Girardin Calcina, potvrdu triju novih kapitula:

1. Svi limari (stagnadori), izraditelji kućanskoga posuđa (conza lavezzi) i slični obrtnici, koji namjeravaju otvoriti obrt u gradu, njegovu okružju i mjestima pod

65 Isto, fol. 5-6.

${ }^{66}$ Dvorana u kojoj se okupljala Bratovština zadarskih kovača bila je u kući naslonjenoj uz crkvu. U 18. stoljeću godišnji zakup te kuće iznosio je 42 lire. Od toga je Bratovština plaćala 24 lire za dvoranu, a najmitelj kuće preostalih 18 lira. HR-AZDN-16/5, Zadarska nadbiskupija/metropolija, Spisi, Nadarbine (beneficiji) - ovjerovljeni prijepisi dokumenata 15. st. i dalje, 18. kolovoza 1705. godine.

${ }^{67}$ Tada su članovi bili kako slijedi:

Geronimo Nadal, gastald, Zuanne Rokini, prok., Francesco Marini, prok., Andrea de Venetia, Zuane da C.anauo, Francesco Bianchi, Nicolo Rossini, Nicolo Parzegnach, Zuanne da Ragusi, Zuanne da Eldene, Cesaro Chijachyo, Agustin Tauelli, Simon Haruatinich, Michel Gliola, Gioanni Battista Genoa, Piero di Maria, Andrea Rimanich, Capo Gierolimo Cigognia archibu. HR-ZKZD-MS50-Mariegola, fol. 19.

${ }^{68}$ Lovorka Čoralić, "Građanske obitelji Arvatini i Cavaletti - prilog poznavanju društvene i kulturne povijesti Zadra u XVII. i XVIII. stoljeću”, Zbornik Odsjeka za povijesne znanosti Zavoda za povijesne $i$ društvene znanosti HAZU 26 (2008): 91. 
gradskom jurisdikcijom, moraju platiti naknadu u visini šest lira i četiri solda (jedan dukat) te iznos od jedne lire i deset soldi (luminaria) ${ }^{69}$ svaki put kada obavljaju posao, a brigu o redovitoj naplati vodit će gastald bratovštine.

2. Svi koji se bave ili se žele baviti kovačkim zanatom izvan grada, u selima na kopnu ili na otocima, dužni su u skladu s kapitulom XXIV. matrikule jednokratno uplatiti Bratovštini pet lira za pokretanje obrta te godišnji doprinos (luminaria), koji plaćaju svi bratimi.

3. Nitko tko ne pripada Bratovštini ne može procijenjivati bilo koju vrstu željezarije, materijala i radova bilo koje vrste pripadajućih kovačkome zanatu. Samo članovi Bratovštine imaju pravo vršiti procjene i odrediti novčanu vrijednost kovačkoga materijala svih vrsta, uključivo u pravnim aktima poput miraza ili bilo koje vrste sporazuma i plaćanja, pod kaznom od 25 dukata u korist siromašne crkve Bratovštine kovača za prekršitelje toga kapitula. Procjenitelje vrijednosti materijala i ostale kovačke opreme, kao i izvršenih radova, ovlastit će o tome poslu gastald Bratovštine kako bi mogao strogo nadgledati da se polovica dobitka od procjene uplati u korist Bratovštine i njezine crkve, a druga polovica procjenitelju za nagradu, kako to prakticiraju druge obrtničke bratovštine, osobito Bratovština zlatara. ${ }^{70}$ Kapitule su potvrdili zadarski knez Bartolomeo Trevisan 13. travnja 1733. godine i generalni providur Zorzi Grimani 4. svibnja 1733. godine. ${ }^{71}$

U studenome 1733. godine članovi Bratovštine izglasali su novi kapitul da svatko tko dolazi u grad s namjerom otvaranja kovačke radionice i srodnih obrta mora proći kvalifikacijski ispit. O tome će poslu Uprava Bratovštine (Banca $)^{72}$ imenovati majstora koji će testirati znanje i iskustvo zainteresiranoga, a ako on zadovolji, treba uplatiti Bratovštini za otvaranje radnje šest lira i četiri solda (jedan dukat). ${ }^{73}$ Prema novim odredbama tijekom 1741. godine uplatili su tako novi kovač u Zadru Petar Marco Albanese i kalcer Luca Albanese svoje obveze zadarskoj Bratovštini kovača. ${ }^{74} \mathrm{Na}$ skupštini 17. listopada 1779. godine Bratovština je s šesnaest glasova za i jednim protiv izglasala da ubuduće novi gastald ne može preuzeti dužnost dok stari gastald ne podmiri sve račune iz razdoblja svojega upravljanja te ne uredi Knjigu troškova (Vachetta). ${ }^{75}$ Stari gastald morao je u roku od petnaest

\footnotetext{
${ }^{69}$ Luminaria je pojam koji označava doprinos Bratovštini, koji su bratimi inače plaćali mjesečno ili tjedno za osvjetljenje oltara i crkava, a u drugome kontekstu označava redovitu godišnju članarinu. Giuseppe Boerio, Dizionario del dialetto veneziano (Venezia: Reale tipografia di Giovanni Cecchini, 1867), 377.

${ }^{70}$ HR-ZKZD-MS50-Mariegola, fol. 28-29.

${ }^{71}$ Isto, fol. 30.

${ }^{72}$ Banca (de scola) je pojam koji označava predsjedništvo, udrugu ili vijeće glavara jedne bratovštine. Mjesto ili stol za kojim oni sjede nazivao se Desco. Boerio, Dizionario del dialetto veneziano, 60.

${ }^{73}$ HR-ZKZD-MS50-Mariegola, fol. 32.

${ }^{74}$ Gastald je tada bio Francesco Antonelli, koji je izabran nakon Zuanea Dominisa (1740.), a prokuratori Pietro Volpi i Giovanni Battista Savio. Isto, fol. 31.

${ }^{75}$ Vachetta je bila knjiga u koju se upisivali dnevni troškovi. Boerio, Dizionario del dialetto veneziano, 776.
} 
dana predati upravu novome gastaldu pod kaznom od deset lira ako bi prekoračio taj rok. ${ }^{76}$

Razvidno je da je broj članova Bratovštine varirao tijekom stoljeća. Koncem 15. stoljeća Bratovština je brojala tridest članova, a u tim okvirima ostala je i tijekom 16. stoljeća. Ti podatci vrijede za sam grad jer je u gradskome okruženju i na otocima također bilo članova Bratovštine kovača pa se konačan broj ne može egzaktno odrediti. Nadalje, unutar Bratovštine bilo je i malverzacija s članstvom, osobito onoga sa zadarskih otoka. Stoga je zadarski knez Christoforo Canal 28. ožujka 1594. godine odredio da se u gradsku Bratovštinu ne može primiti nijedan otočanin ili stanovnik otočnih sela bez dopuštenja zadarskoga kneza. Naime, otočani su se učlanjivali u gradske obrtničke bratovštine kako bi izbjegli obvezu javne tlake (per liberarsi dallobligo dell'angarie personali dellarmar le galie zaratine, e dall altri fattioni personali $)^{77}$ jer su zanatlije od nje bili oslobođeni, ${ }^{78}$ a $\mathrm{k}$ tomu je Bratovština kovača, prema kapitulu XV. svoje matrikule, eventulanu tlaku naplaćivala, čak i vojnicima, ${ }^{79}$ iako je ona u načelu bila besplatna. ${ }^{80}$

U drugoj polovici 16. i tijekom 17. stoljeća u Zadru se bilježi znatniji broj kovača. Primjerice, u popisu stanovništva grada Zadra iz 1527. godine ubilježeni su sljedeći kovači: Hieronimo fabro, Zuan fabro, Piero fabro, Nicolò fabro (dvojica), Stephano fabro, Andrea fabro, Simon fabro, Jadrul fabro, Baressa fabro, Chnex fauro. U popisu je spomenuta i jedna žena - Jelena faura, međutim, nije jasno je li se ona bavila kovačijom ili je preuzela mužev posao $u$ vidu nositeljice obrta ${ }^{81}$ s obzirom na to da se u historiografiji bilježi otpor takvoj praksi. ${ }^{82}$ Roman Jelić navodi broj od 33 kovača koji su izrijekom spomenuti u maticama vjenčanih zadarske katedralne Župe sv. Stošije. Od svih staleža tada su najbrojnije zastupljeni obrtnici. Ubilježeno ih je oko šesto, a za četiristo se izrijekom navodi zanat, dok za dvjesto samo uopćeni naziv mistro (majstor). ${ }^{83}$ Većinom su to bili domaći obrtnici. Kada se Jelićev popis kovača ${ }^{84}$ i ostalih imena koje spominje u maticama vjenčanih bez naznake zanimanja, ${ }^{85}$ usporedi s popisom članova navedenih $\mathrm{u}$

\footnotetext{
${ }^{76}$ HR-ZKZD-MS50-Mariegola, fol. 48.

77 Isto, fol. 9-10.

${ }^{78}$ Šime Peričić, Dalmacija uoči pada Mletačke Republike (Zagreb: Centar za povijesne znanosti, Odjel za hrvatsku povijest, 1980), 51.

${ }^{79}$ HR-ZKZD-MS50-Mariegola, kap. XV, fol. 4.

${ }^{80}$ Peričić, Dalmacija uoči pada, 50.

81 Šime Ljubić, Commissiones et relationes Venetae. vol. I. (1433-1527), Monumenta spectantia historiam Slavorum Meriodionialium, sv. 6 (Zagreb: Sumptibus Academiae scientiarum et artium, 1876), 203-218.

${ }^{82}$ James E. Shaw navodi slučaj iz Venecije kada je udovica nekoga kovača tražila mjesto u udruženju kovača kako bi preuzela mužev obrt, čemu se udruženje snažno protivilo. James E. Shaw, The Justice of Venice. Authorities and Liberties in the Urban Economy 1550-1700 (New York: Oxford University press, 2006), 174-175.

${ }^{83}$ Jelić, "Stanovništvo Zadra", 362.

${ }^{84}$ Isto, 492-493.

${ }^{85}$ Isto, 369-449.
} 
matrikuli, ${ }^{86}$ s pravom se zaključuje da je broj kovača u tome razdoblju bio znatno veći, tim više što je Jelić obradio samo matice vjenčanih. ${ }^{87}$

Raznoliki nacionalni sastav članova Bratovštine zabilježen je u 16. stoljeću za vrijeme Ciparskoga rata (1570. - 1573.), što je razumljivo jer je kovačka djelatnost u to vrijeme bila izrazito tražena, a zacijelo su s pripadnicima stranaca u postrojbama mletačke vojske pristizali i njihovi majstori kovači, koji su prema staroj matrikuli (Mariegola Vecchia) bili dužni uplatiti Bratovštini pet lira za pokretanje obrta. ${ }^{88} \mathrm{O}$ njihovoj nazočnosti svjedoči tužba kovača Geronima di Pezzija iz Brescie, ${ }^{89}$ koji se 2. listopada 1576. godine obratio zadarskome knezu u svoje i u ime ostalih kovača stranaca u gradu da se poništi izbor gastalda i prokuratora Bratovštine jer glasovanju nisu pristupili svi članovi. ${ }^{90}$ Stoga se u sastavu Bratovštine bilježi veći udio stranaca, mahom majstora za izradu mačeva (Spader). ${ }^{91}$ Važno je napomenuti da je mletačka vlada u to vrijeme plaćala kovačkoga pročelnika (proto fauro) u visokome iznosu od dvjesto dukata godišnje, što je 1576. godine reducirano na četrdest dukata. ${ }^{92}$ Jednako se može pretpostaviti za 17. stoljeće, osobito u vrijeme Kandijskoga (1645. - 1669.) i Morejskoga rata (1685. - 1699.) kada se u Zadru bilježi iznimno visoki udio vojničke populacije. ${ }^{93}$ Zamjetno je da su i mletačke vlasti u gradu (knez i kapetan) benevolentnije nastupale prema Bratovštini u ratno vrijeme i odlučnije štitile njezine interese u čestim parnicama. ${ }^{94}$ Po završetku rata, koncem 17. i početkom 18. stoljeća, znatno opada udio kovača u ukupnome broju obrtnika u Zadru. ${ }^{95}$ Zaključno se može utvrditi da se kapituli Bratovštine kovača, kao i kod ostalih bratovština, odlikuju pravnim odredbama za članove sa svrhom religijskoga, odgojnoga, humanoga, kulturnoga, ekonomskoga i političkoag benefita svojih članova. ${ }^{96}$

\footnotetext{
86 Vidi bilj. 53.

${ }^{87}$ Imena pojedinih kovača i članova Bratovštine, naznačena u matrikuli, spomenuta su i kod Jelića, ali bez naznake njihova zanimanja. Primjerice, Francesco Maron, Zuanne Bradich, Domenego de Scutari i Simon Liparelli. Jelić, "Stanovništvo Zadra”, 480, 481, 483.

${ }^{88}$ Usp. HR-ZKZD-MS50-Mariegola, fol. 13.

${ }^{89}$ Bratovština kovača iz Brescije spominje se u srednjemu vijeku u kontekstu templara. Elena Bellomo, The Templar Order in North-west Italy (1142 - c. 1330) (Leiden; Boston: Brill, 2008), 212-214, 319.

90 Isto, fol. 8-9.

${ }^{91}$ Usp. Raukar et al., Zadar pod mletačkom upravom, 384.

92 U relaciji Antonija da Pesara od 7. ožujka 1588. godine navodi se da njegove usluge za vrijeme mira više nisu potrebne, a opterećuju državnu blagajnu. Grga Novak, Commissiones et relationes Venetae, vol. IV. (1572-1590), Monumenta spectantia historiam Slavorum Meriodionialium, sv. 47 (Zagreb: Academia scientiarum et artium Slavorum Meridionalium, 1970), 178, 425.

${ }_{93}$ Usp. Lovorka Čoralić, "Mletački časnici, svećenici, građani - tragom Barana u Zadru (XVII.-XVIII. stoljeće)", Radovi Zavoda za povijesne znanosti HAZU u Zadru 50 (2008): 147-192; Raukar et al., Zadar pod mletačkom upravom, 360-365.

${ }_{94}$ HR-ZKZD-MS50-Mariegola, fol. 16-17.

95 Vidi tablicu kod: Raukar et al., Zadar pod mletačkom upravom, 384.

${ }^{96}$ Usp. Cvitanović, "Bratovštine grada Zadra”, 458.
} 
Nužno je, međutim, sagledati omjer religijskoga i ekonomskoga tekstualnog koncepta matrikule obrtničke Bratovštine kovača u Zadru da bi se dobila jasnija slika njezine djelatnosti i interesne sfere. Čisto religijske bratovštine po svojoj su naravi otvorenijega tipa jer nisu omeđene isključivo profesionalnim parametrima, čak kada su u pitanju bratovštine kleričkoga tipa ${ }^{97}$ dok su zanatlijske bratovštine najvećim dijelom uvjetovane konkretnom profesijom. Nadalje, tek su rijetke obrtničke bratovštine u Dalmaciji bile otvorene ženskim članicama, što je obrnuto proporcionalno religijskim bratovštinama. ${ }^{98}$ Usporedbom kapitula triju religijskih bratovština sa zadarskoga područja ${ }^{99} \mathrm{~s}$ kapitulima Bratovštine kovača zorno se očituje prevaga duhovnih poticaja u tekstu matrikule u prvome slučaju naprama ekonomskim odrednicama teksta matrikule obrtničke Bratovštine kovača u Zadru, što je na tragu zaključka I. Benyovsky da su obrtničke bratovštine s vremenom sve više gubile vjerski značaj, a razvijale se u cehove. ${ }^{100}$

Početkom 17. stoljeća bilježe se pokušaji izbjegavanja plaćanje članarine u Bratovštini. Primjerice, 2. kolovoza 1614. godine utekao se zadarskome knezu Lorenzu Surianu o tome pitanju gastald Zuanne Benvenuti zbog Simona Spadera in Piazza, koji je odbio platiti članarinu. ${ }^{101}$ Uzroci neplaćanja članarine mogu se potražiti u netransparentnome trošenju novca, protivno kapitulima Bratovštine, zbog čega je zadarski knez Pietro Loredan 18. ožujka 1622. godine odredio da se bratimi ubuduće imaju redovito sastajati na čelu s gastaldom i ostalim službenicima Bratovštine kako bi odredili raspodjelu novca, bilo za potrebe crkve i održavanja oltara ili najsiromašnijih obitelji odnosno članova Bratovštine, uz prijetnju ozbiljnih kazni ako se to ne bi u potpunosti izvršilo. ${ }^{102}$ Članovi Bratovštine u svoju su obranu naveli da mnogi kovači mijenjaju kovačnice te prelaze sad u jednu, sad u drugu te na taj način i nisu više članovi Bratovštine, na njezinu ekonomsku štetu. ${ }^{103}$ Trzavice su u Bratovštini bile uzrokovane i tijekom izbora Uprave. Već smo rekli da su se neki strani kovači bunili na izborni proces. Stoga je 28. studenoga 1628. godine zadarski kapetan Pietro da Mosto donio odluku o izboru gastalda Bratovštine. Trebalo je providjeti onoliko kuglica za balotažu koliko je bilo okupljenih članova Bratovštine. Između tih kuglica ubacivale bi se četiri zlat-

\footnotetext{
97 Isto, 465.

98 Vidi rad: Vilma Pezelj, “Žene u bratovštinama srednjovjekovnih dalmatinskih gradova”, Zbornik radova Pravnog fakulteta u Splitu 47 (2010), br. 1: 155-173.

99 Grozdana Franov Živković, "Bratovština (skula) župe sv. Ivana Krstitelja u Tinju i župe sv. Petra i Pavla u Bubnjanima u 18. stoljeću”, Radovi Zavoda za povijesne znanosti HAZU u Zadru 53 (2011): 163-187; Ista, "Bratovštine (skule) župe Blažene Gospe od Luzarija u Preku na otoku Ugljanu u 18. i 19. stoljeću”, Radovi HAZU u Zadru 52 (2010): 231-259; Ista, "Glagoljska madrikula sv. Jakova u Solinama (Dugi otok) od god. 1750. do 1826., Radovi HAZU u Zadru 51 (2009): 137-159.

${ }^{100}$ Benyovsky, "Bratovštine u srednjovjekovnim dalmatinskim gradovima”, 144.

${ }^{101}$ HR-ZKZD-MS50-Mariegola, fol. 10.

${ }^{102}$ Isto, fol. 10-11.

${ }^{103}$ Isto, fol. 14 .
} 
ne kuglice s imenima kandidata koji konkuriraju za mjesto gastalda, a jednako se primjenjivalo pri izboru ostalih službenika Bratovštine. Kazna za prekršitelje iznosila je 25 lira. Mletačka vlast očito je budno pratila aktivnosti Bratovštine, što je u konačnici bilo od posebnoga državnog interesa u smislu kontrole proizvodnoga procesa i naplate državnih poreza. Primjerice, zadarski je knez 1681. godine naredio gastaldu da nabavi novu knjigu za upis troškova (vachetta), koje je kontrolirala državna vlast. ${ }^{104}$

Od iznimne je važnosti za Bratovštinu bilo očuvanje njezinih prava i povlastica s obzirom na kovački zanat, otvaranje novih radionica i uopće nazočnost kovača i srodnih zanatlija u gradu. Jedna od povlastica Bratovštine kovača vezana je uz vojnu obvezu. Sinovi kovača i radnika u kovačnicama nisu se upisivali u Popis vojnih obveznika (Rolo militare). ${ }^{105}$ Oni su se vodili kao Fratelli dell'Arte, a plaćali su godišnji doprinos kao i bratimi. Tijekom 18. stoljeća dolazi do znatnoga opadanja broja kovača u gradu. ${ }^{106} \mathrm{U}$ dokumentima se govori o malobrojnosti članova i postupnome izumiranju toga zanata u gradu, ${ }^{107}$ što je rezultiralo osiromašenjem Batovštine. ${ }^{108} \mathrm{O}$ tome svjedoči dokument od 23. srpnja 1705. godine kada zadarskome nadbiskupu Viktoru Priuliju (1688.-1712.) pišu gastald Michiel Harvatini $^{109}$ te Simon Rossini i Zorzi Florio, prokuratori della Chiesa di S. Gioanni in Posterla da je crkva preuska (angusta) ${ }^{110}$ te je ljeti u njoj prevruće, a zimi, zbog blata, otežan pristup pa ju vjernici zaobilaze i odlaze drugamo na misu, što je u konačnici rezultiralo manjim prihodima Bratovštine za održavanje crkve i oltara. ${ }^{111}$ Stoga su tražili dopuštenje zadarskoga nadbiskupa da se crkva proširi (placet per l'edificatione a fine rissultando più maestoso l'edificio, che ancor si conserva sin da primi secoli), što je odobreno 27 . srpnja 1705 . godine. ${ }^{12}$

\footnotetext{
${ }^{104}$ Isto, fol. 20.

${ }^{105} \mathrm{O}$ mletačkim podanicima i njihovim obrambenim dužnostima vidi više kod: Gaetano Cozzi, Michael Knapton, Giovanni Scarabello, Povijest Venecije, sv. II. (Zagreb: Izdanja Antibarbarus, 2007), 375-382.

${ }^{106}$ Primjerice, 1744. godine navodi se da Bratovština broji osamnaest članova, a koncem 18. stoljeća bilježi se sedam kovača. Zasigurno u broj članova Bratovštine 1744. godine treba uvrsiti i pripadnike srodnih zanatskih umijeća (kotlari, limari...). Usp. HR-ZKZD-MS50-Mariegola, fol. 32; Raukar, Zadar pod mletačkom upravom, 487.

${ }^{107}$ (...) col basso numero quasi in abiettione l'Arte medema. HR-ZKZD-MS50-Mariegola, fol. 28.

${ }^{108}$ Isto, fol. 25.

${ }^{109}$ Moguće je da se radi o istome Mihovilu (H)arvatiniju kojega spominje L. Čoralić. Čoralić, “Građanske obitelji Arvatini i Cavaletti", 91-92, 138.

${ }^{110} \mathrm{Uz}$ crkvu je bila naslonjena kućica, čiju je nadarbinu uživao zadarski kanonik i rektor crkve Sv. Ivana de Pusterla don Ivan Grisogono: (...) Caseta attaccata alla Chiesa stessa trà questi come dissero confini, da Siroco Stradda pubblica da Buorra in parte la Chiesa, et in parte la Sala mentouata che pure uiene confinare per Buora con Stradda pubblica ouero Scalla della Chiesa per Maestro una muraca altre uolte delli heredi Budini, et in parte Capitan Pietro Zagarzanin, et da Garbin Pietro Bubnanich Borghegiano(...). HR-ZKZD-MS50-Mariegola, fol. 23.

${ }^{111}$ Prijedlog je prihvaćen na sastanku Bratovštine sa sedamnaest glasova za, a tri protiv. Isto, fol. 22.

${ }^{112}$ Isto, fol. 22-23.
} 
Slika 2. Crkva Sv. Ivana Krstitelja (Sv. Nediljice)

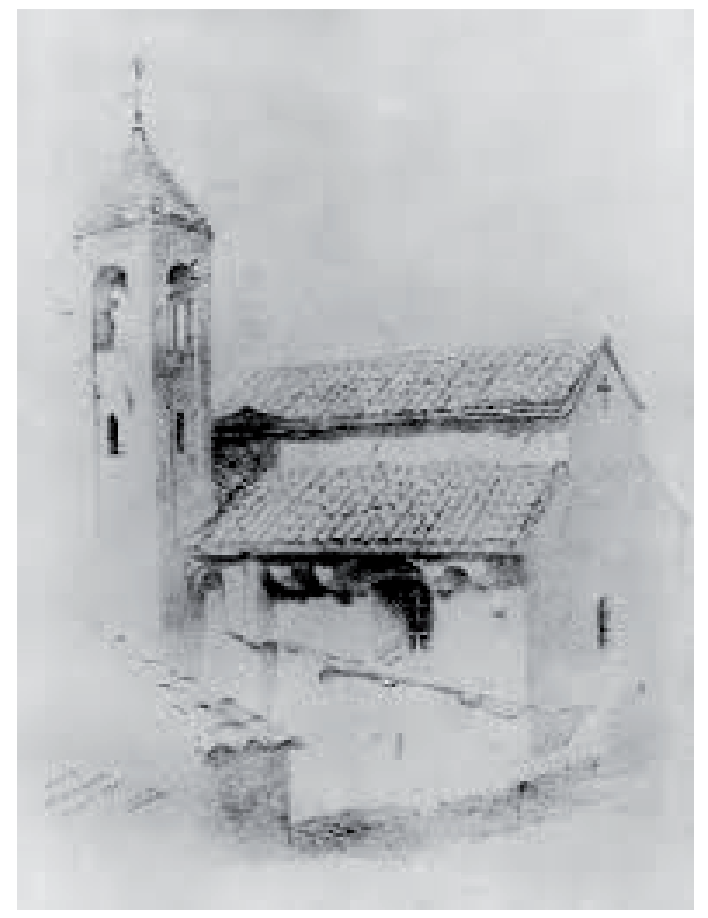

Izvor: V. Brunelli, Storia della Città di Zara, Trieste, 1974, str. 251.

Unatoč nepovoljnim okolnostima za Bratovštinu kovačke usluge i dalje su bile tražene kako u gradu, tako i na selu. Budući da je u gradu ipak bio veći broj kovača, veća je bila i konkurencija, a samim time i manja zarada. S druge strane, na selima su kovači financijski bolje prolazili zbog izostanka konkurencije i sigurne klijentele. ${ }^{113}$ Primjerice, u neposrednoj blizini Zadra, u Bibinjama, Bratovština sv. Roka dala je na korištenje bratimsku kuću kovaču koji je tu radio i živio sa svojom obitelji, a pozvali su ga sami mještani te se s pravom može zaključiti o potrebi i važnosti njegovih usluga za seljane. ${ }^{114} \mathrm{Uz}$ to, kod seoskoga se stanovništva bilježi znatna interakcija s lutajućim zanatlijama i trgovcima u to vrijeme. ${ }^{115} \mathrm{Ne}$ čudi, stoga, što se paralelno u gradu i njegovoj okolici pojavljuje sve veći broj nedomicilnih zanatlija lutalaca (vagabondi stagneri, calderari, conza lauezzi), koji prakticiraju zanat bez poštivanja pravilnika Bratovštine kovača i na njezinu štetu. Stoga su 11. studenoga 1748. godine zadarski sindici inkvizitori Giovanni Battista Loredan, Nicolò Erizzo i Sebastian Molin izdali odredbu o zabrani takvih aktivnosti strancima

\footnotetext{
${ }^{113}$ Marino Berengo, La società veneta alla fine del Settecento (Firenze: Sansoni, 1956.), 67.

${ }^{114}$ HR-AZDN-16/6, Kanonske vizitacije, Vizitacija nadbiskupa V. Zmajevića 1742., Bibinje, kut. 2, fol. $64 \mathrm{v}-65 \mathrm{r}$.

${ }^{115}$ Berengo, La società veneta, 69.
} 
i lutalicama, koji se ne namjeravaju nastaniti u gradu ili njegovu okruženju, pod kaznom zatvora. ${ }^{116}$ No, unatoč prijetnjama i odredbama i kasnije se bilježi nazočnost zanatlija lutalaca u Zadru i njegovu okruženju. Tako je, primjerice, 12. lipnja 1776. godine zadarski knez Zorzi Marin - na tužbu Bratovštine kovača da su neki Napolitanci, ${ }^{117}$ kovači i zanatlije, nedavno pristigli u grad, a ne pokoravaju se pravilniku Bratovštine - iste prognao iz grada i zabranio im rad. ${ }^{118}$ Čini se da je kovače i srodne obrtnike resila iznimna mobilnost između dvije jadranske obale u vrijeme mletačke vladavine. ${ }^{119}$

O dekadenciji Bratovštine i djelomičnome gubljenju kontrole njezine uprave nad kovačkim zanatom tijekom 18. stoljeća zorno svjedoči odredba zadarskih sindika inkvizitora od 29. travnja 1750. godine u kojoj se navodi da se u gradu i njegovu okruženju te na otocima otvaraju kovačke i srodne radionice a da se ne poštuju regule o obveznoj uplati doprinosa u blagajnu Bratovštine. Stoga su sindici odredili da se petnaest dana prije otvorenja radionice najprije trebaju Bratovštini uplatiti doprinosi i godišnja podavanja određena kapitulima, pod prijetnjom kazne od deset dukata za prekršitelje. ${ }^{120}$ Unatoč tome, zanatlije se nisu pokoravale odredbama mletačkih vlasti ni pravilniku Bratovštine. Nepoštivanje regula Bratovštine posljedično je rezultiralo većim brojem sudskih procesa od kojih su neki trajali godinama. Primjerice, u vrijeme gastalda Giovannija Battiste Pescadorija 1753. godine Bratovština je vodila sudski spor protiv Giovannija Battiste Florenzana, ${ }^{121}$ koji je započeo još 1749 . godine, a protegnuo se do 1756. godine kada je gastald Bratovštine bio Gierolimo Antonelli ${ }^{122}$ jer se Florenzan udaljio iz grada pa mu je u odsutnosti određeno da se mora pokoriti bratovštinskim pravilima, pod prijetnjom kazne od visokih stotinu dukata. ${ }^{123}$ Nadalje, u zaštiti vlastitih

\footnotetext{
${ }^{116}$ HR-ZKZD-MS50-Mariegola, fol. 35.

117 Tijekom 18. stoljeća bilježi se razmjerno veliki broj Maltežana i Napolitanaca, trgovaca i zanatlija lutalaca, na području mletačkoga dominija, što je mletački Senat dekretima zabranio. Unatoč zabranama i dekretima M. Berengo navodi da se lutalaštvo nije umanjilo. Berengo, La società veneta, 69,75 . O tematici lutalaštva na području Mletačke Republike koncem 18. stoljeća opširno kod: Francesco Menegheti Casarin, I vagabondi. La società e lo Stato nella Repubblica di Venezia alla fine del '700 (Roma: Jouvence, 1984.).

${ }^{118}$ HR-ZKZD-MS50-Mariegola, fol. 47.

${ }^{119}$ Primjerice, zadarski kovači Petar i Toma Radov zabilježeni su kao članovi Bratovštine Gospe od Umiljenja i Sv. Ivana Krstitelja u Veneciji. Emil Hilje, "Matrikula bratovštine Gospe od Umiljenja i Sv. Ivana Krstitelja u Znanstvenoj knjižni u Zadru”, Ars Adriatica 2 (2012), bilj. 39, 106. Usp. Lovorka Čoralić, Hrvatski prinosi mletačkoj kulturi (Zagreb: Dom i svijet, 2003), 25-129.

${ }^{120}$ HR-ZKZD-MS50-Mariegola, fol. 36.

${ }^{121}$ Isto, fol. 37-38.

${ }^{122} \mathrm{U}$ ispravi od 17. rujna 1768. godine u Zadru u svojstvu svjedoka spomenut je kovač Gaetano Antonelli. U istome svojstvu spominju se 1769. godine i kovači: Marco Orlandi, Giuseppe Ghisalberti i Carlo Polti. Juraj Balić, Lovorka Čoralić, Filip Novosel (prir.), Gradivo za povijest istočnoga Jadrana u ranom novom vijeku, svezak I, Spisi zadarskoga bilježnika Antonija Calogere (1768.-1770.) (Zagreb: Hrvatska akademija znanosti i umjetnosti, 2014), br. 99, 172-173; br. 182, 282-283; br. 31, 321-323; br. 35, 326-328.

${ }^{123}$ HR-ZKZD-MS50-Mariegola, fol. 45.
} 
interesa Bratovština kovača sporila se s ostalim obrtničkim bratovštinama zbog monopola nad sirovinom. U gradu su mnogi prodavali materijal za kovačiju, a nisu bili članovi Bratovštine. U konačnici to je dovelo do sudskoga spora između trgovaca željezom (mercanti da ferro) i zadarskih kovača okupljenih u Bratovštini. Trgovci su, naime, pripadali Bratovštini trgovaca, ali su prodavali materijal kojim su se služili kovači. ${ }^{124}$ Sve gore navedeno nužno je povezati s naglašenim zahtjevima obrtnika u drugoj polovici 18. stoljeća za slobodnim radom neovisnim o korporativnoj upravi ${ }^{125}$ jer je pretenzija obrtničkih bratovština za monopolom znatno kočila razvoj slobodnih zanatlija, što je, uostalom, bilo u interesu Mletačke Republike. ${ }^{126}$

Manjak zanatlija u bratovštinama dijelom je utjecao na neuredno financijsko upravljanje obrtničkim bratovštinama polovicom 18. stoljeća, o čemu svjedoči poduži dopis generalnoga providura Francesca Grimanija od 29. listopada 1754. godine. Mletačka vlast uočila je da su upravljanje bratovštinama preuzele nekompetentne i nelegalno izabrane osobe, a da se novčana sredstva bratovština troše suprotno njihovim regulama. ${ }^{127}$ Stoga je generalni providur donio nove odredbe o izboru upravnih tijela obrtničkih bratovština za područje cijele pokrajine. Za izbor gastalda, prokuratora i ostalih službenika obrtničkih bratovština donesene su sljedeće odluke:

1. Izbor se mora obaviti balotažom ( $a$ bossoli e balotte), a u suprotnom slučaju vlast će poništiti izbor bratovštinske uprave.

2. Generalni providur odredio je da se nova uprava bratovštine ne može birati dok ne istekne vremenski rok od najmanje godine dana od izbora stare uprave (contumacia).

3. Zabranjuje se izbor crkvenih osoba (osobito župnika ili kapelana) u upravna tijela bratovština pod prijetnom kazni određenih zakonom. ${ }^{128}$

4. Svaka obrtnička bratovština dužna je imenovati svoga pisara koji će na sastancima bratovština uredno bilježiti prijedloge, zaključke i odredbe o kojima bratovština raspravlja i upisati ih u zasebnu knjigu.

5. Radi urednoga financijskoga upravljanja bratovštinski novci i ostali kapital mora se pohraniti u blagajnu s onoliko ključeva koliko određena bratovština ima prokuratora, koji su na koncu godine dužni položiti račune predstavnicima vlasti radi revizije i odobrenja.

\footnotetext{
${ }^{124}$ Isto, fol. 15.

${ }^{125}$ Usp. Berengo, La società veneta, $50-53$.

${ }^{126}$ Usp. Cozzi, Knapton, Scarabello, Povijest Venecije, sv. II., 662-668.

${ }^{127}$ HR-ZKZD-MS50-Mariegola, fol. 42.

${ }^{128}$ Stroga odredba za crkvene osobe posljedica je napetih odnosa između Venecije i Rima upravo 1754. godine. O tome više kod: Anton Maria Bettanini, Benedetto XIV e la Repubblica di Venezia. Storia delle trattative diplomatiche per la difesa dei diritti giurisdizionali ecclesiastici. Decreto veneto 7 settembre 1754 (Milano: Vita e pensiero, 1931).
} 
6. Ako neki član uprave bratovštine bez zle namjere pogriješi u upravljanju dobrima, mora obeštetiti bratovštinu u roku od osam dana, a ako do toga dođe zbog njegova nemara ili pronevjere, neka se odmah kazni s naplatom četvrtine pronevjerenoga iznosa (pena del quarto) prema zakonskim odredbama i neka se zauvijek izbaci iz bratovštine i s popisa bratima, s naznakom pronevjere kako bi poslužio za primjer drugima. ${ }^{129}$

\section{Zaključak}

Bratovština kovača u Zadru spada u obrtničke bratovštine čije djelovanje, unutarnji ustroj, matrikule i regule u historiografiji nisu sustavno obrađeni, a izvrsna su povijesna vrela za razmatranje mjesne, nacionalne, ali i europske gospodarske prošlosti uopće. Istraživanje matrikule Bratovštine zadarskih kovača, pohranjene u Znanstvenoj knjižnici u Zadru te dostupne historiografske literature pokazuje da početak njezine ustanove treba tražiti u vremenskome okviru od konca 14. i početka 15. stoljeća pa sve do 19. stoljeća. Analizom njezinih isprava, usporedno s praksom koja je postojala na Apeninskome poluotoku, moguće je pretpostaviti poveznicu s Bratovštinom zlatara u Zadru, no uslijed nedostatka arhivskoga gradiva ta rasprava ostaje otvorena. Poput ostalih zadarskih bratovština ona je djelovala sukladno kapitulima svoje matrikule, a prvotni joj je cilj bio braniti interese svoga zanata, čime se bitno razlikuje od religijskih bratovština, kojima je svojstvenija duhovna dimenzija djelovanja. Tijekom stoljeća razvidna je znatna oscilacija u brojčanome članstvu Bratovštine, što je usko povezano s ratnim događanjima na području mletačke Dalmacije, osobito Ciparskoga (1570.-1573.), Kandijskoga (1645.-1669.) i Morejskoga rata (1684.-1699.), ali i zahtjevima za slobodnom praksom zanatlija, neovisnom od korporativne uprave bratovština, osobito u drugoj polovici 18. stoljeća. Njezino djelovanje u pravnim i ekonomskih okvirima, s obzirom na obrtničku odrednicu, uvelike je bilo uvjetovano odredbama i odlukama političkih vlasti, dok su duhovne i religijske aspekte Bratovštine regulirale crkvene vlasti u Zadru. Poput mnogih zadarskih bratovština i ona je ukinuta u vrijeme francuske uprave u Dalmaciji.

${ }^{129}$ ZKZD, Mariegola, sign. 10365, ms. 50, fol. 43-44. 
Prilog. Prijepis matrikule Bratovštine kovača u Zadru. Izvor: HR-ZKZD-MS50Mariegola, fol. 1-6.

(fol. 1) In nome della Santissima Trinità, della Beatissima Vergine Maria et di Sant Alò prottetor della Scola de fabri di Zara

Concio sia cosa, che il nostro Signore Optimo et Eterno Iddio crease l'huomo de humana natura et similitudine della sua figura celeste, non e però l'huomo sufficiente ad alcuna opera senza l'invocazione e subsidio de esso Optimo et Eterno Iddio et per tanto a principio mezo e fine del presente libro nel quale li ordini e statuti della Scuola e frattaglia delli fabri della Città di Zara ... al nome del Nostro Signor Miser Giesu Christo imenso Ottimo ed Eterno Iddio e della Sua Gloriosissima, e Beatissima Madonna ed advocata dell'humana natura Madona Santa Maria, e del Glorioso Euangelista Mis(er) San Marco Prottetor e Difensor della Città di Zara sia etiamdio invocato il nome del Glorioso S. Grisogono, San Simon, et Madonna Santa Anastasia devoti Protettori della Città di Zara e della detta Scuola et Fratalia delli fabri di Zara che alli infrascritti ordini e statuti dia, et conceda buon principio miglior mezzo et per felicissimo fine, accio che in vigore et osservantia de essi sia alli suoi santissimi nomi, santissime laude gloria, e riverentia et etiamdio accio che i sia o laude et reverentia della nostra Illustrissima et Eccellentissima Ducal Signoria di Venezia et alla quale l'Altissimo Iddio per bene comune della Città di Zara se degnasse conservare per lunghissimi tempi (fol. 2) sotto ombra et Dominio della qual vivere se possa tranquille, et patientemente cum buon stato prospero, et felice. Sia etiamdio ad honor, gloria, laude, et reverentia dello Illustrissimo Principe, et Eccellentissimo Signor Miser Agostino Barbadico per Dio Gratia Inclito Duce de Venetia et et delli Mag(nifi)ci Generosi Rectori della Città de Zara Miser Zuan Marco Bembo honorevole Conte, Maffio Baffo honorevole Capitaneo, et de tutti quelli, che amano el ben, et Stato del Comune, et Dominio de Venetia per infinita saeculorum saecula. Amen.

Millesimo Quadrigentesimo Nonagesimo Indictione Octava Die vero prima mensis Septembris Iadrae. Hij sunt infrascripti Magistri Fabri Cives et habitatores ac laboratores Artem Fabrorum in Civitate Iadrae; Qui pro bono, et utili, ac communi pace, et quiete totius suae Fraternitatis in simil existente et concorditer composuerunt infrascripta Capitula. Nomina suprascriptorum Fabrorum sunt infrascripta, videlicet, et primo.

Pre(sbyter) Mattio Usanich Capellan

Luca el Protomagistro

Magistro Andrea Gastaldo

Magistro Mattio Procurator

Mag(istr)o Menio Biliacovich Proc(urato)r 
Magistro Cressole

Magistro Fraxis.o [Francisco?]

Magistro Marin Glubicich

Magistro Marco

Magistro Martin Ucinovich

Magistro Lucaz Benzich

Magistro Iurai Vianovich

Magistro Franco Vencovich

Magistro Marco Zarucha

Magistro Andrea Utiscenovich

Magistro Mattio Charaniza

Magistro Gregorio Vianovich

Magistro Piero

Magistro Paulach Garzanrich

Magistro Valenta

Magistro Marco Zelencovich

Magistro Thomaso

Magistro Zorzi Spader

Magistro Zuan Spader

Magistro Antonio de Mandella

Magistro Andrea Spader

Magistro Gregorio Spader

Magistro Stephano Spader

Magistro Paxin Calderer

Magistro Giacomo Favro figlio de Pasin

Magistro Simon Spader Scerobich

Omnes vero suprascripti contentaverunt de omni, et toto eo quod consistetur in infrascriptis Capitulis, quorum tenor seguitur, et est talis, videlicet;

\section{(fol. 3) Capitulo Primo}

Primo, se alcuno dirà villania al Gastaldo cada in pena de liure cinque, la mittà al Commun di Venetia, l'altra mittà alla Fraternità delli ditti Fabri. Et similiter chi li menesse le mano adosso debbia pagare liure diexe alla Frataglia. 


\section{Capitulo Segondo}

Item se alcuno dirà villania alli Procuratori, ò uero li mettesse le mano adosso cada in pena de liure tre, reseruando el Criminale.

\section{Capitulo Terzo}

Item chi dirà villania alli nostri Officiali, ò uero li metterà le mano adosso cada in pena de liure duo alla Frataglia.

\section{Capitulo Quarto}

Item se tutti li Fratelli non ueniranno alla Scola tutte le Feste principali; cioè Natale, Pasqua, Pentecoste, Anno nuouo, Epiphania, et el dì della Festa nostra, cada in pena de soldi diece per uno.

\section{Capitulo Quinto}

Item, che li sopraditti Gastaldo, et Procuratori habbiano plenaria libertà di fare alto, et basso, et tutto quello meglio à loro parerà per bene, et utile della ditta Fraternità, senza contradittione de alcuna persona.

\section{Capitulo Sexto}

Item se alcuno contradicesse alle soprascripte cose, cazano in pena de liure diece da esser scosse senza remissione.

\section{Capitulo Septimo}

Item quando el Gastaldo cum li suoi Procuratori uorrà congregar li Fratelli, et manderà per loro, et loro si saranno negligenti, ò uero disobedienti, et non ueniranno, cadano in pena de liure duo per cadauno contrauerrà.

\section{Capitulo Octauo}

Item quando uignisse à mancar qulach'uno delli Fratelli, ò uero alcuno de casa sua chi non uenira accompagnarlo alla sepoltura cada in pena de soldi diece per cadauno.

\section{Capitulo Nono}

Item, se alcuno desuiasse el Fameglio de un'altro, che non hauesse compito el suo tempo, cada in pena de liure diece, et di Zonta pagando le liure diece el tutto Fameglio torna cum el primo, et che' 1 Patron cazzandolo senza legitima caxon, 
debbia pagar el suo salario, et se' 1 Patron senza caxon non debbia hauere el suo salario.

\section{Capitulo Decimo}

Item, che tutti lauoranti siano tenuti à pagar una candella de soldi quattro, reseruando li Famegli sono à tempo et una lira all'anno de luminate.

\section{(fol. 4) Capitulo Vndecimo}

Item se' 1 fusse fatto alcuno Offitiale, et quello refudasse el suo uffitio cada in pena de lire cinque.

\section{Capitulo Duodecimo}

Item, che niunposa ouer pressuma comprar, nè far marcà de carboni fuora de Zara, sotto pena de liure cinque.

\section{Capitulo Tertiodecimo}

Item, che nissuno ardischi, ò uero pressuma co(m)prar carboni ad ingrosso fin,che no' daga notitia alli fratelli, che cadaun possi co(m)prar, cum questa ceduo, che' 1 sia tenuto di darne a chi uorrà, essendo lui antemesso de uno sacco. Et se alcuno uolesse de ditti carboni, et se alcuno ne uorrà, siano tenuti dargli la parte, et se alcuno non ne uorrà, possa cadauno comprar dimandando licentia al nostro Gastaldo, et chi contrafarà cada in pena de liure diece.

\section{Capitulo Quatrodecimo}

Item, che' 1 nostro Gastaldo sia tenuto cum li suoi Offitiali mandar per la elemosina se dà per le Isole, et Ville, et se loro non mandasseno, siano tenuti satisfar el danno segondo sarà stimato per li Fratelli della prenominata Scola delli Fabri.

\section{Capitulo Quintodecimo}

Item che cadauno, cosi soldato, come altra persona sia tenuto à pagar le angarie, le qual saranno poste à nui, cioè Galie, Guardie, et le Candelle, et Guardie de Fano alle Porte, et chi contrafarà cada alla pena de liure cinque alla Frataglia nostra da esser applicade.

\section{Capitulo Sextodecimo}

Item cadaun mag[aze]no el qual uignisse à uender le suo caldare à Zara, et stesse piu de Zorni quindese à uender le suo caldare, sia tenuto di pagare la candella alla 
nostra Frataglia sotto pena de liure duo da esser diuisa ut supra, cioè alla Frataglia; intendendo in questo numero li Conzari, li quali portano la baschiera per la Terra conzando caldare, et alrti stagnadori.

\section{Capitulo Septimodecimo}

Item, che coloro, i qual uanno lauorando de botega in botega siano tenuti pagare la mittà delle angarie, altramente chi lo riceuesse in la sua botega caschi alla pena de liure duo da essere diuise ut supra alla Frataglia, le qual tutte pene debbano esser scosse, et diuise senza remission alcuna.

\section{Capitulo Octauodecimo}

Item, che tutti coloro, i quali uenissero à uendere à Zara, conzar, ò uero lauorar peteni da stoppa, ouer lino, ò uero per el Contado siano tenuti à pagar tutte le angarie de galie, fuste, guardie, et altre angarie usade, come fanno tutti li altri fauri di Zara.

\section{Capitulo Nonodecimo}

Item, che nissuno Fauro da Zara, ò uero pressuma acalar alcuno gomero nuouo per mando de soldi quattro l'uno in pena de liure duo da esser diuise ut supra alla Frataglia, et similiter se intenda delli Fauri lauorano de fuori per el Contado, che' 1 sia in libertà de andar dachi li farà migliore mercato.

\section{Capitulo Vigesimo}

Item, se alcuno uenisse, cosi Terriero, come del Contado à qualche botega de fauro per far qualche lauoriero, et un'altro fauro quelli tal desuiasse per andar, ò farlo andare à qualche altra botega in danno del primo caschi alla pena de liure cinque; la mittà alla Frataglia, l'latra mittà all'Accusatore.

\section{Capitulo Vigesimo primo}

Item, che niuno Fabro de Zara sia de che condition se uoglia osa, ò uero pressuma portar alcuno lauoro di ferro, sia di che sorte se uoglia per uendere per la Città de Zara el dì da Domenega, in pena de liure duo da essere scosse senza remissione, et date alla Frataglia.

\section{Capituolo Vigesimo segondo}

Item, se per lo Gastaldo, et Procuratori della Scola delli Fauri segondo le loro usanze alcuno fusse sententiato, ouer condemnato; quel tal condemnato, ò uero 
sententiato per niente se possa aggrauare dauanti alcuno altro Giudice, et uogliando contrafar, ò uero aggrauarse cada alla pena de liure cinque da esser scosse, et diuise ut supra. Intendendosi in le cose appartien alla Scola, et non in altro; cum questo tamen non possano condannare più de liure tre.

\section{Capitulo Vigesimo tertio}

Item, che tutti li Spadari, li quali habitano in la Città de Zara siano tenuti, et obligati à pagar tutte le angarie occurrenti, come fanno tutti li fauri della Città de Zara, che pagano le angarie solite.

\section{Capitulo Vigesimo quarto}

Item, che cadauna persona sia de che condition se uoglia, el quale leuasse la botega da nuouo della nostra arte de Fauri sia tenuto de pagare alla nostra Scola, ò Frataglia liure cinque, il quale poi sarà trattato da buon fratello.

\section{Capitolo Vigesimo quinto}

Item, che cadauno delli nostri Fratelli, el qual non uegnisse el dì della buona intrada della nostra Illustriss(ima) Signoria auanti, che siano partiti della Chiesa per andar alla Procession, cada in pena de soldi octo.

\section{Capitulo Vigesimo sexto}

Item attrouandose alcuno qual se sia di nostri Fratelli, el quale dicesse uillania uno allaltro quando fossamo congregati in Scola per alcuno nostro besogno cada in pena de liure duo, et che siano scosse senza ogni remissione per la Frataglia.

\section{(fol. 5) Capitulo Vigesimo septimo}

Item cadauno Gastaldo, che uenisse à scriuere, ò uero per altri facesse scriuere le spese della Frataglia altroue, che in libro grande paghi liure quattro.

\section{Capitulo Vigesimo octauo}

Item se' 1 ditto Gastaldo tolesse, ò uero acceptasse che roba se uole della Fratalea, cioè delle elemosine, che' 1 ditto Gastaldo lui solo non pressuma, ne' debbbi; mà che chiami uno de' Procuratori, ò uero di altri Offitiali, et cosi accepti le ditte robbe; aliter contrafazzando à tal ordene, caza in pena de liure quattro senza remission per la Frataglia di essere scosse, et alla Scola applicate. 


\section{Capitulo Vigesimo nono}

Item se qualch'uno di Famegli, ò uero lauorenti fosse di tanta temerità, che uenisse à dire uillania al suo Maestro, ò che lo ingiuriasse maxime in presentia delle persone caschi in pena eo tunc de liure tre per ogni uolta contrauegnirà à questo ordine.

\section{Capitulo Trigesimo}

Item, se li ditti Fratelli si trouassene insieme in qualche etiamdio non per besogno della Fraternità, et che uno inguriasse l'altro, ò uero li duesse uillania maxime mel fare di officiali caschi in pena de soldi diese.

\section{Capitulo Trigesimo primo}

Item el Gastaldo compiando el suo tempo, et non rendando el conto d'ogni cosa alli Fratelli in termine de Zorni uinti di tutto quello hauerà administrato mentre nell'offitio sarà stato, caza in pena de liure diese, et senza ogni remissione da essere scosse, la mittà per la Camera di S. Marco, l'altra mittà per la nostra Scola, ò uero Fraternità, che tutti quanti Christo Omnipotente ne conserui cum li suoi Santi. Amen.

\section{Capitulo Trigesimo segondo}

Item se qualch'uno di nostri fratelli se attrouasse, che fosse latro, et subito, che sarà discoperto, che sia discacciato fuori della nostra Fraternità senza ogni remissione, et che non possi ancor lauorare cum neuno di nostri Fratelli, mà che li sia data total repulsa come à membro euitabele.

\section{Capitulo Trigesimo tertio}

Item, che li Spaderi per più habilita possano frà loro Spaderi elezere uno experto per Zudese, che hauerà à giudicare li loro lauorieri segondo richiede la condecentia, et.

(fol. 6) NOS IO: Marcus Bembo pro Ill.mo et Exc.mo Ducali Dominio Veneto etc. Comes Iadrae, et Districtus. Cum coram Nobis presentata fuisset praesens Matriculla Scolae, et Frataleae Fabrorum huius Fidelissimae Ciuitatis Iadrae, ut ipsam dionemini ad honore Dei et ad bonum, utile, et $\operatorname{com}(\mathrm{m})$ odu $(\mathrm{m})$ d.tae Scolae, et Frataleae co(n)firmare, et ratificare, visu pertotum dica Matriculla, et visis omnibus Capitulis in ea descriptis, quae omnia dedicata sunt ad divinum cultum, et ad honorem Ill.mi Du: Do: nostri Venetiar(um), ac huius Regiminis Iadrae, omnibus bene, et diligenter perspectis, et consideratis, Auctoritate Magistratus 
nostri ipsam Matricullam cum omnibus suis capitulis in ea contentis laudauimus, approbauimus, et ratificauimus, ac tenore presentium ratificamus, approbamus, et laudamus in totum, et per totum pro et in presenti libello, ea Matriculla continetur. Nostram, et Magistratus nostri auctoritatem pariter, et indiuiate decretum interponendo. In quorum fidem etc.

Data Iadrae die XX. mensis Aprilis MCCCCLXXXXI. Indicatione Nona. Ego Io. Marcus Bembo Comes Iadrae subscripsi.

Ego Antonius Barba Monsil. Notarius pub. Iadrae et. Coad.r Canc.ae M.ci D. Comitus praefati ma(n)dato. 


\section{Arhivi}

Hrvatska - Arhiv Zadarske nadbiskupije - fond 16 - Zadarska nadbiskupija/metropolija, Liber Extraordinariorum II (1746-1767) (HR-AZDN-16)

Hrvatska - Arhiv Zadarske nadbiskupije - fond 16/5 - Zadarska nadbiskupijal metropolija, Spisi, Nadarbine (beneficiji) - ovjerovljeni prijepisi dokumenata 15. st. i dalje. (HR-AZDN-16/5)

Hrvatska - Arhiv Zadarske nadbiskupije - fond 16/6 - Zadarska nadbiskupijal metropolija, Kanonske vizitacije, Vizitacija nadbiskupa V. Zmajevića 1742. (HRAZDN-16/6).

Hrvatska - Arhiv Zadarske nadbiskupije - fond 52 - Varie/Razno - Matrikula bratovštine zlatara (HR-AZDN-52).

Hrvatska - Znanstvena knjižnica Zadar - sign. 10365, ms. 50 - Mariegola de favri di Zara (HR-ZKZD-MS50).

\section{Objavljeni izvori i literatura}

Aldobrandini, Pietro. Statuti, riformationi, et ordini dell'Università, et huomini dell'Arte de fabri, \& orefici della ilustre Città, e Stato di Camerino, confirmati, et approvati da' sig. padroni di Roma. Camerino: Gioioso Francesco, 1613.

Almansi Sabbioneta, Carla, ur. L'Arte degli Orefici. Storie di mercati, mercanti ed artigiani in Cremona dal Trecento all'Ottocento. Cremona: Camera di commercio, 2006.

Antoljak, Stjepan. “Zadarski katastik 15. stoljeća”. Starine JAZU u Zagrebu 42 (1949): 371-417.

Balić, Juraj; Čoralić, Lovorka; Novosel, Filip, prir. Gradivo za povijest istočnoga Jadrana u ranom novom vijeku, svezak I, Spisi zadarskoga bilježnika Antonija Calogere (1768.-1770.). Zagreb: Hrvatska akademija znanosti i umjetnosti, 2014.

Belamarić, Joško. “Šutnja protomajstora bazilike San Marco u Veneciji - razriješena”. Radovi Instituta za povijest umjetnosti 12-13 (1988-1989): 97-107.

Bellomo, Elena. The Templar Order in North-west Italy (1142 - c. 1330). Leiden; Boston: Brill, 2008.

Benvenuti, Angelo de. Storia di Zara dal 1409 al 1797. Milano: Fratelli Bocca, 1944.

Benyovsky, Irena. "Bratovštine u srednjovjekovnim dalmatinskim gradovima". Croatica Christiana periodica 22 (1998), br. 41: 137-160.

Berengo, Marino. La società veneta alla fine del Settecento. Firenze: Sansoni, 1956.

Bettanini, Anton Maria. Benedetto XIV e la Repubblica di Venezia. Storia delle trattative diplomatiche per la difesa dei diritti giurisdizionali ecclesiastici. Decreto veneto 7 settembre 1754. Milano: Vita e pensiero, 1931. 
Bianchi, Carlo Federico. Zara Cristiana I. Zara: Tipografia Woditzka, 1877.

Bianco, Rosanna. "Culto e iconografia di sant'Eligio in Puglia tra Medioevo ed età moderna”. Studi Bitontini 95-98 (2013-2014): 7-26.

Boerio, Giuseppe. Dizionario del dialetto veneziano. Venezia: Reale tipografia di Giovanni Cecchini, 1867.

Brunelli, Vitaliano. "Confraternita de' fabbri-ferrai in s. Domenica". Il Dalmata, (Zadar) 8, 10, 11, 12, 13, 14, 17 (1877).

Brunelli, Vitaliano. Storia della Città di Zara. Trieste: Edizioni Lint, 1974.

Cozzi, Gaetano; Knapton, Michael; Scarabello, Giovanni. Povijest Venecije, sv. II., Zagreb: Izdanja Antibarbarus, 2007.

Cvitanović, Vlado. "Bratovštine grada Zadra". U: Zadar Zbornik: geografija, ekonomija, saobraćaj, povijest, kultura, uredio Jakša Ravlić, 457-470. Zagreb: Matica hrvatska, 1964.

Čoralić, Lovorka. "Građanske obitelji Arvatini i Cavaletti - prilog poznavanju društvene i kulturne povijesti Zadra u XVII. i XVIII. stoljeću”. Zbornik Odsjeka za povijesne znanosti Zavoda za povijesne i društvene znanosti HAZU 26 (2008): 87-141.

Čoralić, Lovorka. "Izvori i literatura o bratovštinama u Dalmaciji od srednjeg vijeka do pada Mletačke Republike". Croatica Christiana periodica 15 (1991), br. 27: 88-96.

Čoralić, Lovorka. "Mletački časnici, svećenici, građani - tragom Barana u Zadru (XVII.-XVIII. stoljeće)”. Radovi Zavoda za povijesne znanosti HAZU u Zadru 50 (2008): 147-192.

Čoralić, Lovorka. Hrvatski prinosi mletačkoj kulturi. Zagreb: Dom i svijet, 2003.

Ervas, Alessandro; Fazzini, Gerolamo. "Il ferro a Venezia". Archeo Venezia 15 (2005), br. 1-4: 1-4.

Franov Živković, Grozdana. "Bratovština (skula) župe sv. Ivana Krstitelja u Tinju i župe sv. Petra i Pavla u Bubnjanima u 18. stoljeću”. Radovi Zavoda za povijesne znanosti HAZU u Zadru 53 (2011): 163-187.

Franov Živković, Grozdana. "Bratovštine (skule) župe Blažene Gospe od Luzarija u Preku na otoku Ugljanu u 18. i 19. stoljeću”. Radovi Zavoda za povijesne znanosti HAZU u Zadru 52 (2010): 231-259.

Franov Živković, Grozdana. "Glagoljska madrikula sv. Jakova u Solinama (Dugi Otok) od god. 1750. do 1826." Radovi Zavoda za povijesne znanosti HAZU u Zadru 51 (2009): 137-159.

Galletti, Filippo. "Le società delle arti a Bologna e i loro statuti: un bilancio storiografico". I quaderni del m.ee.s 15 (2017): 69-93. 
Grbavac, Branka. "Svakodnevni život notara u jednoj kasnosrednjovjekovnoj dalmatinskoj komuni - primjer Zadra”. Javni bilježnik 14 (2010) 33: 29-34.

Hilje, Emil. "Matrikula bratovštine Gospe od Umiljenja i Sv. Ivana Krstitelja u Znanstvenoj knjižni u Zadru”, Ars Adriatica (2012), br. 2: 97-108.

Jelić, Roman. "Stanovništvo Zadra u drugoj polovici XVI. i početkom XVII. stoljeća gledano kroz matice vjenčanih". Starine 49 (1959): 349-509.

Klaić, Nada; Petricioli, Ivo. Zadar u srednjem vijeku. Zadar: Filozofski fakultet, 1976.

Kolanović, Josip; Križman Mate, ur. i prev. Zadarski statut: sa svim reformacijama odnosno novim uredbama donesenima do godine 1563. Zadar: Matica hrvatska, Ogranak; Zagreb: Hrvatski državni arhiv, 1997.

Ljubić, Šime. Commissiones et relationes Venetae. vol. I. (1433-1527), Monumenta spectantia historiam Slavorum Meriodionialium, sv. 6. Zagreb: Sumptibus Academiae scientiarum et artium, 1876.

Menegheti Casarin, Francesco. I vagabondi. La società e lo Stato nella Repubblica di Venezia alla fine del '700. Roma: Jouvence, 1984.

Novak, Grga. Commissiones et relationes Venetae. vol. IV. (1572-1590), Monumenta spectantia historiam Slavorum Meriodionialium, sv. 47. Zagreb: Academia scientiarum et artium Slavorum Meridionalium, 1970.

Ostojić, Ivan. "Stara bratovština presvetog Tijela Kristova u Splitu”, Bogoslovska smotra 46 (1977), br. 3: 310-323.

Perez González, Jordi. "Aurifices en la Roma Julio Claudia. La fiebre del oro romana". Studia antiqua et archaeologica 23 (2017), br. 1: 37-70.

Peričić, Šime. Dalmacija uoči pada Mletačke Republike. Zagreb: Centar za povijesne znanosti, Odjel za hrvatsku povijest, 1980.

Pezelj, Vilma. "Žene u bratovštinama srednjovjekovnih dalmatinskih gradova". Zbornik radova Pravnog fakulteta u Splitu 47 (2010), br. 1: 155-173.

Raukar, Tomislav; Petricioli, Ivo; Švelec, Franjo; Peričić, Šime; Foretić, Dinko. Zadar pod mletačkom upravom. Zadar: Narodni list: Filozofski fakultet, 1987.

Saverio di Martiis, Mario. "Lavoro e salute in Europa prima della rivoluzione industriale". Rivista degli infortuni e delle malattie professionali 1 (2010): 119-162. Shaw, James E. The Justice of Venice. Authorities and Liberties in the Urban Economy 1550-1700. New York: Oxford University press, 2006.

Vežić, Pavuša. "Bazilika Sv. Ivana Krstitelja (Sv. Nediljica) u Zadru. Prilog poznavanju ranoromaničke arhitekture u Dalmaciji”. Radovi Instituta za povijest umjetnosti 23 (1999): 7-16. 


\section{Zdenko Dundović*}

\section{Fraternity of Blacksmiths in Zadar and its register from the 15 th century}

\section{Summary}

The register of Zadar's Fraternity of Blacksmiths is preserved at the Scientific Library in Zadar. Based on the text of the register, the author has examined the basic regulations of the Fraternity of Blacksmiths in order to reconstruct its activities and the names of its members. The investigated documentation has been compared with the previously published scholarly literature on the Fraternity of Blacksmiths and the incomplete $19^{\text {th }}$ century presentation of the register by Vitaliano Brunelli has been complemented. The aim of the paper is to indicate that the Fraternity of Blacksmiths in Zadar was established before 1490, contrary to what Brunelli erroneously stated, and to raise questions about its possible links to the Fraternity of Goldsmiths in Zadar.

Keywords: Fraternity of Blacksmiths, register, Zadar, $15^{\text {th }}$ century, Vitaliano Brunelli

* Zdenko Dundović, Department of Religious Sciences, University of Zadar, Trg kardinala Stepinca 1, 23000 Zadar, Croatia, E-mail: zdundovic@unizd.hr 